\title{
Marcelismo e ruptura democrática no contexto da transformação social portuguesa dos anos 1960 e 1970 ${ }^{1}$
}

\author{
Manuel LOFF \\ Universidade do Porto
}

\author{
Marcelism and Democratic Breakdown in the Context of \\ Portuguese Social Changes during the Sixties and Seventies
}

\begin{abstract}
RESUMEN
Al interpretar los años '50 y, sobre todo, los '60 como un ciclo de cambio estructural muy rápido en la sociedad portuguesa, años en los que una verdadera revolución industrial se desarrolla a par del éxodo rural, la emigración masiva y la politización creciente en consecuencia de la Guerra

Colonial (1961-74), el marcelismo nos aparece como la última oportunidad de la dictadura portuguesa ante un proceso de modernización y masificación de la sociedad que tenía mucho de inevitable. La lectura que intentaré exponer parte no del marcelismo en cuanto objeto autónomo de análisis, sino de la lectura del período que separa la crisis del salazarismo de 1958-62 de la caída del
\end{abstract}

\begin{abstract}
Reading the 1950's and, mostly, the 1960's as an historical cycle of structural and speedy change in Portuguese society, a time of real industrial revolution together with rural exodus, massive emigration and growing politicization as consequence of the Colonial War (1961-74), Marcelism emerges as the last chance of the Portuguese dictatorship to control a modernization and massification process which had become clearly inevitable. The interpretation I am proposing does not perceive Marcelism as an autonomous object of analysis, but integrates it in a period running from the 1958-62 crisis of Salazarism until the final breakdown, in 1974 , of the regime. This may be read as an historical cycle of fast (although it can
\end{abstract}

\footnotetext{
1 Este texto resulta da transformação e actualização de um outro que, sob o título de «Fim do colonialismo, ruptura política e transformação social em Portugal nos anos Setenta», publiquei in LoFF, Manuel; Pereira, Maria da Conceição Meireles (coords.) (2006), Portugal, 30 anos de Democracia (1974-2004). Porto: Editora da Universidade do Porto, pp. 153-93. Uma primeira aborrdagem da questão foi preparada, elm língua castelhana, para a jornada de debate Canvi social i canvi polític. Portugal, Itàlia i Espanya: tres països del Sud d'Europa durant els anys setanta no Centre de Cultura Contemporània de Barcelona, em Setembro de 2000, a convite da Fundació Cipriano García - Arxiu Históric de Comissions Obreres de Catalunya, com a colaboração do C.C.C.B., Archivio del Lavoro di Milano e do Grup de Recerca sobre l'Ėpoca Franquista da Universitat Autònoma de Barcelona, e que contou com a participação dos professores Carme Molinero e Pere Ysàs (U.A.B.) e Maurizio Magri (Università degli Studi di Milano-Bicocca). Uma primeira versão da sua tradução foi produzida por Vasco Mota Pereira.
} 
régimen (1974) como un ciclo histórico de rápida (aunque perspectiva de los eventos políticos pueda parecer más lenta) concreción de procesos de cambio social y económico que propiciarían, en 1974, la inevitabilidad de la ruptura democrática. En otras palabras, no se propondrá una interpretación de la Historia reciente portuguesa enfocada en el marcelismo, los años 1968-74, como impulso hacia el cambio, sino como puro período transicional, integrable, además, en un período más amplio que, en mi percepción de las cosas, habría empezado en 1958, diez años antes de la vuelta de Caetano al poder, y el momento en el que, justamente, Salazar le interrumpía su breve delfinato empezado a mediados de los ‘50. be perceived as slow as far as the political events are concerned) materialization of the social and economic change which provided, in 1974, the inexorableness of the democratic rupture. In other words, I am not proposing to underline Marcelism's role in recent Portuguese History as an impulse for change, but merely as a transitional period, clearly assimilated in a wider period which, from my point of view, began in 1958, ten years before Caetano got back to power, the moment in which, in fact, Salazar interrupted his short political experience as heir-to-be of the dictator.

\section{KEYWORDS:}

Salazarism. Caetano's Reformism. Social and Economic Changes. Political

Pressures. Democracy

PALABRAS CLAVE:

Salazarismo. Reformismo marcelista. Transformaciones sociales y económicas. Politización y Democratización

Podemos falar historicamente do Marcelismo como um conceito politicamente consistente na História contemporânea portuguesa? Foram os cinco anos e meio de governo de Marcelo Caetano, à frente dos destinos do regime idealizado por Salazar e por este gerido durante 40 anos, um período com identidade própria suficiente para poder ser definido como um modelo de regime, ou, pelo menos, um padrão de gestão de um modelo prédefinido?

Pessoalmente, responderia negativamente a todas estas questões. A interpretação que aqui tentarei expor parte não do Marcelismo enquanto objecto de análise, mas sim da leitura do período que medeia entre a crise do Salazarismo de 1958-62 e a queda do regime como o de uma rápida (ainda que na leitura dos eventos políticos possa parecer mais lenta) concretização de processos de mudança social e económica que terão propiciado, em 1974, a inevitabilidade da ruptura democrática. Por outras palavras, neste curto ensaio, não se proporá uma leitura da História recente portuguesa centrada no Marcelismo, nos anos de 1968-74, como impulso para a mudança, mas sim como puro período transicional, integrável, ainda por cima, num período mais amplo que, na minha percepção das coisas, teria começado em 1958, dez anos antes do regresso de Caetano à ribalta do Poder, muito pouco tempo antes, justamente, da interrupção do delfinato que Salazar lhe parecia ter oferecido em meados da década de 1950. Nesta perspectiva, o Marcelismo não tem uma identidade politicamente própria — deve ser lido, pelo contrário, como fase final, e mais intensa, de um processo social, eco- 
nómico e, finalmente, político de esgotamento da ditadura e de transição para a democracia, e para uma democracia particularmente diferente, pelo menos na sua fase inicial, de qualquer expectativa reformista que o Marcelismo pudesse ter alimentado...

\section{PORTUGAL, 1960-74: UMA SOCIEDADE EM TRANSFORMAÇÃO, RUMO À CONTEMPORANEIDADE}

Para o estudo da ruptura da dominação autoritária e, consequentemente, do contexto no qual a Revolução do 25 de Abril emerge, rompedora, na trajectória contemporânea portuguesa, creio ser fundamental reflectir sobre a emergência em Portugal de uma sociedade de massas. Essa expressão da modernidade instalouse na sociedade portuguesa nos anos 1960's e os 1970's. Procurarei justificar, ao longo deste ensaio, a ideia de ser quase certo que só depois de tal ocorrer é que poderiam os portugueses protagonizar um processo revolucionário como o de 1974-76 e construir uma democracia. E creio ser assim porque até então não fora possível perceber que a grande maioria da sociedade portuguesa partilhava um conjunto de códigos e símbolos culturais que só a escola e alguns meios de comunicação de massa, justamente, conseguem propor e, as mais das vezes, impor; não existira até então um sistema de produção que incluísse redes de trocas económicas que colocassem em relação verdadeiramente todos os tipos de produção e de produtores; não se verificara até então um nível de concentração urbana suficientemente significativo e que resultasse de movimentos migratórios muito amplos e mais ou menos simultâneos, que propiciassem contemporaneamente uma desruralização suficiente para que arrancasse a industrialização e a terciarização qualificada da economia, bem como um consumo mais ou menos generalizado e padronizado; não havia sido até então suficientemente forte o conjunto dos instrumentos de mobilização (Estado, igrejas, organizações sociopolíticas de massas) que permitissem suscitar reacções verdadeiramente simultâneas aos acontecimentos políticos, sociais e económicos que marcam um verdadeiro quotidiano colectivo; e, por fim e por consequência, não se percebera até então na maioria da população uma forte politização que permitisse divulgar e desenvolver, de forma generalizada, séries mais ou menos coerentes de interpretações ideológicas da realidade social.

O que procurarei aqui sustentar é que a Guerra Colonial, lida aqui como a experiência histórica mais massivamente mobilizadora e transformadora da História contemporânea portuguesa, ao ocorrer num processo em curso de industrialização, urbanização e êxodo rural, veio acelerar e dramatizar várias das mudanças que estavam já a alterar a sociedade portuguesa bem antes da Revolução do 25 de Abril, contribuindo para que a inevitável crise do regime não pudesse ser resolvida por um processo de transição controlada. 


\subsection{A mudança socioeconómica}

Façamos, então, um esforço para visualizar numa espécie de flash a sociedade portuguesa dos anos ' 60 e '70. Quanto mais afastamos a lente e depuramos a nossa percepção do que, ao longe, vemos que se mexe, ganha cor, ganha identidade - o que percebemos? Antes de mais, um movimento incessante: uma parte muito, mas mesmo muito, significativa da população move-se de um lado para o outro, primeiro mais lentamente, depois muito depressa. São os homens, e sobretudo os homens adultos mais jovens, que protagonizam a grande maioria deste movimento, desta pressa em mudar, resolver as suas vidas, emigrando para o estrangeiro ou procurando outra vida numa das duas áreas metropolitanas do litoral português, sobretudo a de Lisboa; em qualquer caso, correndo para próximo de Paris, de Lisboa, do Porto, secundariamente para alguma grande cidade da Renânia industrial, na Alemanha, ou para algum ponto de New Jersey ou do Massachussetts, na Costa Leste dos Estados Unidos, ou ainda para Caracas, na Venezuela, trocando o mundo rural pelo (sub)urbano. Se o não fizeram antes de cumprir o serviço militar, desde 1961 que o Estado, que nesses anos começaria a interferir nas suas vidas muito mais que em algum momento do passado havia interferido na vida dos portugueses, os empurrava em números elevadíssimos para dois anos (e depois de 1968, para quatro anos) nas fileiras do que se transformara num dos mais numerosos exércitos da Europa, empenhado numa guerra de contraguerrilha nas três grandes colónias portuguesas em África: Angola (desde Fevereiro de 1961), Guiné (desde 1963), Moçambique (desde 1964).

Nunca na nossa história em tão curto período de tempo tantos mudaram (social, geográfica e experiencialmente) os destinos das suas vidas. Caso único na Europa, a população do então chamado território metropolitano português baixa de 8,89 para 8,61 milhões $(-3,1 \%)$ nos anos ' 60 ; a queda é evidente sobretudo na franja dos 15-64 anos (-4,7\%). Esta situação demográfica verdadeiramente excepcional ocorria numa fase em que a natalidade portuguesa tinha o nível mais elevado de toda a Europa Ocidental e Central: nasciam por ano mais de $200 \mathrm{mil}$ crianças, cerca do dobro das que nascem actualmente e mais do dobro do número de pessoas que anualmente morriam (cf. BARRETO, 1996: tabela 1.10). Calcula-se que 1,43 milhões de pessoas terão deixado o país nos anos 1960-74. Em 1960, antes de começar a guerra em Angola, emigraram 33 mil, mas em 1962, um ano depois do início da guerra em Angola, o número já subira para 38 mil, em 1965 para 117 mil, em 1970 para 173 mil... No total daqueles 14 anos, mais de $40 \%$ viuse obrigado a fazê-lo de forma ilegal (e de forma crescente com os anos), pagando a passadores minhotos, transmontanos ou beirões, sujeitando-se, na calada da noite, a caminhadas de muitos kilómetros através da chamada raia seca, outras vezes agachados em barcaças que atravessavam o rio Minho, aterrorizados com a possibilidade de que um guarda civil espanhol os apanhasse numa qualquer estrada secundária, ou já dentro de um autocarro ou de um comboio a caminho de França, e os mandasse de volta, para uma realidade quotidiana tão plena de 
constrangimentos que os havia forçado a uma decisão tão difícil quão determinante nas suas vidas. Mais de três em cada cinco destes emigrantes ficou-se por França, um em cada oito pela Alemanha Ocidental, outros tantos pelos Estados Unidos, muito poucos, já, pelo Brasil, ao contrário do que sucedera durante os cem anos anteriores (cf. BAGANHA, 1999).

Fora destas contas encontravam-se aqueles poucos, comparativamente com estes contingentes, que terão preferido deixar-se ficar, uma vez cumprido o serviço militar, feita a guerra, por alguma das colónias africanas, especialmente por Angola (onde em 1974 viviam cerca de 170 mil mais portugueses que em 1961 - cf. BENDER, 1980: 322) e só secundariamente por Moçambique, de alguma forma contribuindo assim para a política oficial do Salazarismo de consolidar a soberania portuguesa nas possessões africanas graças ao reforço da supremacia branca. Ao contrário do que esperariam os próceres da ditadura colonial, é com o conjunto destes números que se pôde dizer que os portugueses tinham votado com os pés contra aquela que era então a opção fundamental para a qual a ditadura havia empurrado o país.

Até ao início da década de ' 80 , pelo contrário, a população portuguesa voltará a subir, até atingir os 9,83 milhões, número para o qual terá contribuído o chamado retorno a Portugal de quase meio milhão de pessoas que, em 1981, diziam residir nas excolónias em Dezembro de 1973, muitas das quais, ao ter nascido nelas, dificilmente poderiam ser consideradas retornadas. Haverá que acrescentar a estes números os cerca de 100 mil soldados portugueses que se encontravam destacados em 1974 para as frentes de guerra africanas e, sobretudo, os $182 \mathrm{mil} \mathrm{emi-}$ grantes que regressam então a Portugal entre 1975 e 1981 e que quase compensam os pouco mais de 200 mil que emigram no mesmo período (cf. CÓNIM, 1992, e BAGANHA, 1999).

O Portugal rural e interior havia entrado, entretanto, num processo de convulsão interna que mais se pareceu com uma implosão das suas estruturas seculares. Os dez anos que separam 1960 de 1970 constituíram a década que mais rapidamente agudizou a sangria populacional do Portugal rural - e, consequentemente, o desequilíbrio entre o litoral e o interior. Em 1973, nas vésperas da implantação da democracia, viviam nos distritos de Bragança e Vila Real, respectivamente, menos $22,7 \%$ e $18,3 \%$ habitantes que em 1960; nas Beiras interiores, as percentagens variavam entre menos $25,2 \%$ na Guarda e menos $14 \%$ em Viseu, com Castelo Branco numa posição intermédia; no Alentejo interior, o êxodo fora mais notório ainda: menos $20,3 \%$ em Évora, menos $25,2 \%$ em Portalegre, menos $31,3 \%$ em Beja; em vários concelhos destas regiões a quebra populacional, só entre 1960 e 1970, havia rondado ou sido superior até aos 40\% (Mértola, Miranda do Douro, Vila Nova de Foz Côa, Sabugal, Ourique; mais próximo do litoral do Continente, Pedrógão Grande). Pelo contrário, cresciam a olhos vistos as zonas suburbanas do que são hoje as Áreas Metropolitanas de Lisboa e Porto, as quais, no seu conjunto, passariam de reunir menos de 2,4 milhões de ha- 
bitantes em 1960 (26,5\% da população portuguesa) a quase 2,8 milhões em 1970 (31,9\%); enquanto os municípios de Lisboa e Porto, em vias de terciarização, perdiam já habitantes, à volta de Lisboa cresciam desmesuradamente concelhos como o do Seixal $(+86,1 \%)$, Barreiro $(+68,3 \%)$, Loures $(+63,1 \%)$, Sintra $(+55,6 \%)$ ou Cascais $(+55,4 \%)$; os subúrbios do Porto cresciam menos acentuadamente: mais $29,1 \%$ de habitantes tinha Espinho em 1970, Gondomar crescera 24,2\%, Valongo $23,9 \%$, Matosinhos $20 \%$. Mesmo que dificilmente se pudesse dizer que o país se urbanizava (em 1970, não mais de $26,5 \%$ dos portugueses vivia em povoações de mais de 10 mil habitantes), a verdade é que ele se suburbanizava, pelo menos. $^{2}$

O modelo especificamente português de concentração regional das alterações produzidas pelas migrações e pelo desenvolvimento industrial e urbano propiciou um desequilíbrio que favorecia de forma inegável o litoral, ao mesmo tempo que, não apenas desvalorizava o interior do país, mas também incitava ao seu despovoamento. É evidente que as alterações no tecido económico ajudavam enormemente a explicar toda esta evolução. Vejamos o seguinte quadro:

EVOLUÇÃO DO EMPREGO EM PORTUGAL CONTINENTAL (in SANTOS, 1989: 131)

\begin{tabular}{|l|c|c|c|c|}
\hline & \multicolumn{2}{|c|}{1960} & \multicolumn{2}{c|}{1973} \\
\hline Emprego total & \multicolumn{2}{|c|}{3.112 .000} & 3.124 .300 \\
\hline & Emprego & P.I.B. & Emprego & P.I.B. \\
\hline Sector primário & $43,6 \%$ & $25,1 \%$ & $26 \%$ & $12,2 \%$ \\
\hline Sector secundário & $28,7 \%$ & $36,5 \%$ & $36,7 \%$ & $51,7 \%$ \\
\hline Sector terciário & $27,7 \%$ & $38,4 \%$ & $37,3 \%$ & $36,1 \%$ \\
\hline
\end{tabular}

O Portugal rural, elemento estrurante da identidade histórica do país e condicionador profundo dos seus ritmos de mudança, entrara irreversivelmente numa fase de transformação e regressão rápidas. Nos anos ' 60 e nos primeiros anos ' 70 , anteriores à queda do regime autoritário, esse Portugal rural sobredimensionado, contra o qual pareciam terem-se estilhaçado até então as principais linhas de força das mudanças históricas da contemporaneidade, evolui de tal forma que, em 1973, não ocupa mais de um quarto do emprego dos portugueses, e um oitavo do seu rendimento.

De entre a série de factores de mudança socioeconómica que actuam neste âmbito, o quadro reflecte um fenómeno de industrialização de baixo nível (tecnológico, de produtividade), iniciado na década anterior, mas que, fracassadas algumas tentativas anteriores de consolidação de um tecido industrial nacional, abre finalmente o seu caminho na economia portuguesa nos anos '60 até representar

2 Para todos estes dados, cf. BARRETo, 1996: cap. 1. 
metade do rendimento nacional em vésperas da queda da ditadura. Se o sector terciário é aquele que, durante idêntico período, mais emprego gera, a sua comparativamente escassa produtividade reserva-Ihe uma porção relativamente baixa do rendimento.

Os últimos quinze anos da ditadura foram, muito contra a vontade do Salazarismo e de um patronato por ele protegido, anos de uma significativa melhoria do nível salarial dos portugueses, o que é ainda mais relevante se tomarmos em conta que havia aumentado fortemente o trabalho feminino, uma vez que este era pago a níveis bastante inferiores do trabalho masculino, desigualdade salarial que, como bem sabemos, continua ainda hoje a discriminar as mulheres portuguesas. Mudanças substanciais nas relações laborais, que se processavam debaixo de um autoritarismo político que limitava os direitos do trabalho desde os anos ' 20 , ter-se-ão dado para que dos $37,8 \%$ que correspondiam, em 1958/59, ao peso das remunerações salariais (excluídas as contribuições patronais à Previdência Social) no conjunto do rendimento nacional (cf. SANTOS, 1989: 133), se passasse para $50,3 \%$ em 1973. Não nos surpreenderá que no clímax do período revolucionário esses números subissem para 55,6\% em 1974 e até $68,5 \%$ em 1975, excepção evidente numa economia capitalista. Contudo, era bom que tivéssemos consciência de que já no final da década de ' 70 , com aquilo a que o pensamento dominante actual chama a progressiva normalização do processo político e social português, o peso do factor trabalho no conjunto do rendimento nacional tinha regredido para 56,5\% (1979), e para 51,7\% quando o cavaquismo conquistou a sua primeira maioria absoluta parlamentar (1987) (LEÃO, 1992: 177, 187, 197). Em terrenos socioeconómicos como este, os anos ' 80 já coincidiam com os últimos anos da ditadura, e os últimos 15 anos vieram até a acentuar uma tendência ainda mais desfavorável aos trabalhadores. Também aqui, evidentemente, os anos da Revolução e do pósrevolução representaram um momento excepcional e irrepetido da nossa história, quase como se se tivessem tratado de um parêntesis.

No campo da saúde, se a evolução verificada ao longo dos anos '60 já foi acentuada, será a democracia a trazer, como nos diz a nossa memória colectiva, avanços radicais. Peguemos, também aqui, nuns quantos dados reveladores. Em 1960, o número de consultas médicas prestada em média a cada português por ano, em estabelecimentos de saúde, não chegava a uma; dez anos depois, subira para duas, em 1975 para 2,7 e em 1980 para quase 2,9. Em 1960, as urgências haviam atendido o equivalente a menos de $6,6 \%$ dos portugueses, e o equivalente a $5,2 \%$ haviam sido internados em algum momento do ano; em 1970, estas proporções subiram para $10,5 \%$ e 7,2\%, em 1975 para $22,7 \%$ e 8,4\%, e em 1980 para $48,5 \%$ e $9 \%$, respectivamente. Coerentemente, cada cem mil portugueses dispunham, em 1960, de 79,6 médicos, e o número não subiria espectacularmente durante os anos '60 (94,7 em 1970), mas sim, pelo contrário, depois do 25 de Abril (119,3 em 1975, 196,8 em 1980). Um bom exemplo tanto da evolução da prestação dos serviços de saúde mas também da mudança de mentalidades é o da proporção de partos assistidos: no início da década de ' 60 , apenas $18,4 \%$ dos qua- 
se 220 mil partos foram medicamente assistidos em estabelecimentos de saúde; dez anos depois a percentagem subira para o dobro (37,5\%) e outros dez anos mais tarde, em 1980, voltaria a duplicar para $73,8 \%$ de um total de 159 mil partos. Em 1960, mais de um em cada oito portugueses que morreram nesse ano haviam sido vítimas de tuberculose ou de uma doença infecciosa ou parasitária; dez anos depois, essa proporção havia descido para 1/18, e em 1980 para 1/71 (cf. BARRETO, 1996: cap. 2).

\subsection{Massificação social e (re)politização de massas}

O sistema social passava da mesma forma e, seguramente pela primeira vez na sua história, por um processo de massificação que arrastou a maioria da população portuguesa para outras experiências e vivências sociais que, em si mesmas, tinham muito de políticas. Antes de mais, a da escolarização. Se a estratégia salazarista de uso intensivo com fins ideológicos e doutrinais da formação básica havia, desde os anos ' 30 , implicado uma descida gradual do analfabetismo literal (40,4\% daqueles com mais de 7 anos em 1950, 32,1\% em 1960, 26,2\% em 1970) -e, no entanto, este se mantinha de longe o mais alto de todo o continente europeu-, concluía-se uma etapa de generalização do ensino obrigatório dos primeiros quatro anos, que, não obstante as reservas explícitas por parte do Estado, fazia disparar a exigência de um ensino secundário e superior, por parte da duvidosamente chamada classe média e da maioria dos estratos populares urbanos, processo naturalmente acentuado pela democratização do país.

ALUNOS MATRICULADOS (números absolutos em milhares; índice) ${ }^{3}$

\begin{tabular}{|l|c|c|c|}
\hline & $1960 / 61$ & $1970 / 71$ & $1980 / 81$ \\
\hline ENSINO SECUNDÁRIO $^{1}$ & $115,4-100$ & $243,7-211$ & $394-341$ \\
\hline ENSINO SUPERIOR $^{2}$ & $24,1-100$ & $49,5-205$ & $87,3-362$ \\
\hline
\end{tabular}

$17 .^{\circ}-11 .^{\circ}$ anos de escolaridade, tipo liceal e técnico, público e privado.

2 Universitário e não-universitário, público e privado.

No terreno das práticas culturais, contudo, nem todas acompanharam este crescimento da escolarização. Umas apresentaram um ritmo de crescimento superior. Foi o caso do uso público das bibliotecas: as 89 bibliotecas existentes em Portugal em 1960 tinham tido nesse ano menos de um milhão de leitores; em 1973

3 Elaboração própria com base em dados de José Salvado SAMPAIO (1973), Evolução do Ensino em Portugal. Metrópole, 1940-41/1966-67 (contribuição monográfica). Lisboa: Fundação Calouste Gulbenkian, e (1980), Portugal. A educação em números. S.I.: Livros Horizonte; UNESCO (1982), Para uma política de educação em Portugal, trad. port. [ed. ori. francesa: 1975]. S.I.: Livros Horizonte; E. Marçal GRILo [1994], «O sistema educativo», in António REIS (coord.), Portugal. 20 anos de democracia. S.I.: Círculo de Leitores, pp. 406-35. 
tinham passado a existir 257, com 3,2 milhões de leitores; em igual medida, o número de consultas anuais quase triplicou entre 1960 e o final da década. Quanto à imprensa, e sendo impossível dispor de números fidedignos quanto a tiragens e, sobretudo, à leitura efectiva de jornais, a verdade é que os primeiros anos ' 70 , antes ainda do 25 de Abril, parecem ter constituído uma fase excepcional na história da imprensa escrita portuguesa: o número total de jornais e periódicos, $468 \mathrm{em}$ 1960, atingiria os 1316 em 1973, nível não mais atingido, curiosamente, até 1995 (cf. BARRETO, cap. 8).

Algumas outras práticas culturais permaneceram claramente restritas no seu âmbito elitista: no conjunto estatístico da afluência aos espectáculos de música, bailado e variedades, os dados relativos aos anos ' 60 variaram em torno dos 150-180 mil espectadores anuais (com excepção de 1968: 262 mil), nível que, por exemplo, superava largamente o dos anos 1980's e que só voltaria a ser ultrapassado a partir de 1991. Por outras palavras, o equivalente a dois em cada cem habitantes assistia uma vez por ano a tais espectáculos na década de 1960. Nestes anos, o teatro era uma arte performativa incomparavelmente mais popular do que é hoje, e muito mais alta era a sua frequência: o número de espectadores por ano naquela década andou à volta de 1,1-1,3 milhões, número que se reduziria gradualmente para descer abaixo dos 250 mil em 1997. O espectáculo cultural público com mais sucesso em Portugal, como no resto do Mundo em que irrompera a cultura de massas, permanecia o cinema, apesar de os anos '60 serem já sinónimo de estagnação: 25,1 milhões de bilhetes vendidos em Portugal em 1960, 23,2 milhões em 1965, 26,5 milhões em 1973. Será literalmente a democratização e o fim da censura a permitir um boom do interesse pelo cinema, já em contraciclo com o resto do Mundo, muito especialmente durante o período revolucionário: 32,8 milhões de espectadores em 1974, 38,7 em 1975, 40,5 em 1976, decaindo depois ininterruptamente até aos pouco mais de 7 milhões em 1994 (cf. BARRETO, 1996: cap. 8).

Outro factor que explica a relativa pujança do cinema nos hábitos de massas em Portugal tem a ver com o impacto tardio da Televisão, que só surge em 1957 e que manterá audiências relativamente baixas quando comparadas com o resto da Europa ou a América do Norte. Em 1958, a R.T.P. não cobre mais do que $44 \%$ do território continental, onde viviam 58\% dos portugueses; só em 1972 chegará à Madeira, e em 1975 aos Açores. Mais significativo ainda é dizer que em 1959 não estavam vendidos mais do que 32 mil receptores de TV, número que subiria para 68 mil em 1961 e para 450 mil em 1964; em 1967, calculava-se que o número de telespectadores andaria por volta dos 2,2 milhões, cerca de um quarto da população, portanto. ${ }^{4} \mathrm{Em}$ todo o caso, é difícil garantir que a TV tenha tido ainda antes do 25 de Abril um peso muito significativo nas vidas e nos processos de formação de opinião e de gostos da grande maioria dos portugueses. Semelhante

${ }^{4}$ Cf. António ReIS (1989), "A televisão: arma do poder e janela para o mundo», in António REIS (dir.), Portugal Contemporâneo, vol. V. S.I.: Pubs. Alfa, pp. 203-06. 
afirmação já seria possível fazer, por exemplo, relativamente apenas aos jovens do mundo urbano e às camadas da pequena e média burguesia; mas não, isso não, ao universo popular, sobretudo rural. Para tanto haveria que esperar pela democracia.

Por outro lado, o conjunto da sociedade era afectado por um traumático fenómeno de mobilização militar para uma Guerra Colonial que, desencadeada em 1961 em Angola, se havia estendido à Guiné e a Moçambique. Duas gerações, grosso modo, de jovens são arrastadas pelo regime para África, chamadas às fileiras durante dois anos, que passam a quatro em 1968, dois dos quais obrigatoriamente cumpridos em África. O resultado estatístico é impressionante: 920 mil homens são mobilizados nos treze anos que dura o conflito, 250 mil outros escapam (os refractários) à incorporação, quase todos emigrando ilegalmente, a salto. Se recordarmos que os Estados Unidos num conflito de dimensões tão importantes como o do Vietname, ocupando um percurso cronológico semelhante e paralelo ao da guerra colonial portuguesa, superando-o um pouco, aliás, deverão ter mobilizado cerca de duas vezes e meia o número de homens mobilizados pela ditadura portuguesa, numa população 25 vezes superior à nossa, poderemos ter uma perspectiva mais nítida do tremendo esforço imposto aos portugueses pela opção militar de Salazar, reiterada por Caetano. E se esse é o resultado estatístico, assustador é o resultado humano: oficialmente, e se atendermos ao contingente militar metropolitano, são assumidos 9 mil mortos, 28-32 mil feridos, e um número entre 30 e 120 mil, segundo diferentes critérios médicos e políticos, de excombatentes padecendo de uma neurose de guerra. As Forças Armadas portuguesas jamais divulgaram números de quantas vítimas terão sido feitas entre população civil e guerilheiros africanos, calculando-se, no entanto, entre 30 e 50 mil angolanos mortos (SILVEIRA, 1989: 88-89) em represálias (os chamados contramassacres) que se desencadeiam por todo o Noroeste de Angola apenas nos primeiros seis meses de guerra em Angola, e sem contar com aqueles perpetrados nos muceques de Luanda no primeiro semestre posterior ao assalto às prisões da capital angolana, do 4 de Fevereiro de 1961), número necessariamente muito inferior ao somatório das vítimas de 13 anos de combates nas três frentes de combate.

\subsection{A iminência da ruptura sociopolítica}

De um modo geral, portanto, e partindo desse pressuposto de que nos finais dos anos '50 dificilmente podemos qualificar a sociedade portuguesa como sendo já de massas, é razoável concluir que a mudança socioeconómica começa muito antes da mudança sociopolítica, pelo menos no plano das suas manifestações explícitas. Neste último campo, a sociedade portuguesa ressentia-se de uma larguíssima tradição autoritária da representação simbólica e das práticas do poder social e político, que nem o liberalismo elitista monárquico (1834-1910) e nem o republicano (1910-26) conseguiram ou sequer procuraram inverter. 
No contexto europeu, em Portugal tinham sido muito incipientes os níveis de participação política e associativa nos anos '20, o período final e socialmente mais reivindicativo da I República, e até esses seriam rapidamente reprimidos as primeiras décadas de ditadura. Em nenhum momento anterior da época contemporânea tinham sido constituídas organizações sociais e políticas autenticamente de massa e independentes do Poder político.

Neste contexto, tenhamos bem presente que só a introdução do sufrágio universal, nas eleições constituintes de 1975 , no ano da queda da ditadura, vem encerrar verdadeiramente um século e meio de hegemonia absoluta de diferentes concepções elitistas da participação e cidadania políticas ${ }^{5}$. Não terá sido simples casualidade que fórmulas políticas tão diferentes como a Monarquia Constitucional dos Braganças, a República mais ou menos jacobina, mas antioperária, e um Salazarismo que casava, como vários outros regimes europeus casaram, modernidade fascista e tradicionalismo católico, tenham partilhado todas uma ideia tão restritiva do cidadão (no masculino, exactamente, porque todos os eleitores portugueses até 1933 foram homens, e quase todos até 1975, em qualquer caso) politicamente activo e, consequentemente, eleitoralmente habilitado. Por cima dos programas doutrinários mais específicos de cada um desses regimes pairava uma mesma cultura política profundamente elitista que fazia praticamente coincidir direitos políticos com uma identidade social burguesa, culturalmente definida pela escolarização. Se nas últimas eleições marcelistas anteriores ao 25 de Abril apareciam recenseados para votar apenas $23 \%$ dos portugueses (o que representava grosso modo $35 \%$ dos maiores de idade de ambos os sexos), a evolução nem sequer tinha sido muito significativa se os comparássemos com os $19 \%$ de inscritos em...1890, ou os $15 \%$ das eleições presidenciais de 1958. É neste contexto que não será difícil perceber que as organizações sociopolíticas criadas no período revolucionário se revelem ainda profundamente marcadas pela iniciativa de redes de personalidades das elites sociais, numa lógica de capilaridade organizativa de cima para baixo.

Em todo o caso, o problema político central que motivou a desestruturação do sistema político da ditadura, levando, por fim, a sociedade à consciência da insuportabilidade do autoritarismo, é o da crise definitiva do paradigma colonial, que o Salazarismo havia inserido no segundo pósguerra mundial, preparando conscientemente, e com eficácia conjuntural, a resistência à vaga emancipadora dos povos da Ásia e de África. É inevitável que nos detenhamos um pouco a analisar uma questão que, ao longo de toda a época contemporânea, propiciou que se configurasse um verdadeiro Sonderweg português, uma via pela qual seguiram pro-

5 Cf. o meu (1998) «Electoral Proceedings in Salazarist Portugal (1926-1974): Formalism and Fraud in a 150-year old Context of Elitarian Franchise», in RomAnELLI, Raffaele (ed.), How Did They Become Voters? The History of Franchise in Modern European Representation. The Hague/London/Boston: Kluwer Law International, pp. 227-250 [Versão espanhola: «El proceso electoral salazarista (1928-1974) en el contexto de 150 años de sufragio elitista», in MORENo FONSERET, Roque (ed.), Plebiscitos y elecciones en las dictaduras del sur de Europa (siglo XX). Alcoy: Editorial Marfil, pp. 175-200.] 
blemática política, economia e identidade nacional portuguesas, aparentemente distintas daquela seguida pela generalidade das sociedades à sua volta.

Depois dos colonialismos nacionalistas liberais do segundo e do último quartel do século XIX e o republicano do primeiro quartel do século XX, o Salazarismo concebeu nos anos ' 30 um primeiro colonialismo, de semântica assumidamente imperial e tom fascista, que se tornaria necessariamente inadequado à realidade emergente da derrota nazifascista de 1945. Desde os últimos anos da guerra e até à reforma constitucional de 1951, prepara-se dentro das fileiras do regime um magma ideológico e simbólico com o qual se pretendeu reformular a dimensão colonial portuguesa, o qual, justamente, coincidia com uma fase de verdadeira consolidação da presença administrativa, militar e económica do seu estruturalmente débil colonialismo.

Como em todas as (re)definições identitárias segregadas e impostas por um aparelho político, começava-se por uma explicação pseudohistórica mais ou menos pedagógica. De maneira semelhante ao que tinham sustentado todas as anteriores versões do nacionalismo português, defendia-se que a independência de Portugal tinha dependido sempre da conservação das suas colónias. Na conjuntura de um pósguerra em que assumiam protagonismo os nacionalismos asiáticos e árabes, e na qual se via surgir o mais que certo «wind of change» soprado pela «African national Consciousness» de que falaria em 1960 o Primeiro Ministro britânico MacMillan, a elite política e intelectual do Salazarismo recupera uma vez mais a tese mais ou menos tradicional de que reconhecer o direito à autodeterminação das colónias significaria expor Portugal aos apetites espanhóis. Por estes tempos, mais do que em conjunturas passadas, o património colonial aparecia, com alguma razoabilidade no plano teórico (mas apenas nesse, como a realidade se encarregaria de demonstrar), como uma das bases sobre as quais se podia construir o modelo económico de desenvolvimento industrial e comercial que o regime salazarista decide, finalmente, assumir. A lógica emergente é a de que a solvência económica portuguesa dependia desse laço fundamental com, antes de mais, África, em aberta contradição com o rumo então imposto por todas as demais potências europeias.

O regime salazarista começa por resistir diplomática e ideologicamente no plano internacional, para logo levantar armas contra a rebelião armada dos movimentos de libertação nacional das colónias africanas. No primeiro caso, contra si tem uma Índia recém independente que exige o abandono dos três enclaves portugueses (Goa, Damão e Diu) — o que acabará por ocorrer em Dezembro de 1961 -, e, a partir de 1956, a maioria anticolonialista da O.N.U., uma plataforma aguerrida face à qual se foi revelando, ano após ano, o isolamento internacional do Governo português, pese embora a sua tentativa de se apresentar na vanguarda da "defesa da civilização europeia» contra os «imperialismos» soviético e chinês.

Submetido à pressão do emancipalismo, o Salazarismo opta por limpar parcialmente a fachada do sistema colonial português, assumindo tardiamente as dou- 
trinas francesas do assimilacionismo cultural e político dos indígenas ou nativos, substituindo na Constituição, em 1951, a terminologia colonialista típica (Ultramar em vez de Império Colonial, e Províncias Ultramarinas em vez de Colónias), sem fazer desaparecer, até 1961, a discriminação essencial do Estatuto do Indigenato, cuja última versão impõe em 1954, três anos depois da revisão constitucional a que aludi. $O$ mundo académico e político decidia-se, por fim, a investir nas investigações sociais que serviriam o novo modelo assimilacionista, supostamente original no conjunto das experiências coloniais da História moderna e contemporânea. As décadas de '50 e '60 são anos da recuperação académica e política do luso-tropicalismo, criação anterior do brasileiro Gilberto Freyre ${ }^{6}$, que na experiência portuguesa de contacto com o mundo tropical encontra "convivência multirracial», «paternalismo brando», "colonialismo antieconómico», teses que até ao final da II Guerra Mundial não teriam acolhimento favorável dos construtores da ideologia colonial portuguesa, incomodados com argumentos que favoreceriam a visão que desde as demais potências coloniais europeias se tinha do colonialismo português - a de um modelo pobre e incompetente de dominação colonial.

A repressão violenta de toda a mobilização de índole social, política ou simplesmente identitária que se detectasse no espaço colonial, leva, ao fim de uma década, os movimentos de libertação à opção pela luta armada, em 1961 em Angola, em 1963 na Guiné, em 1964 em Moçambique. O conflito torna-se, rápida e inevitavelmente, um verdadeiro beco sem saída possível dentro do âmbito do regime autoritário, pela acumulação de problemas que representa. Antes de mais, pela tensão que provoca entre necessidades de desenvolvimento socioeconómico e a «imobilização de recursos pela guerra colonial» (SANTOS, 1989): se já num período de preparação para o embate militar, cerca de $36 \%$ da despesa pública metropolitana the é dedicado em 1958, oito anos passados desde o início da guerra chega-se aos 55\% (1969), e num momento de profunda crise económica internacional (1973) a não menos de $46 \%$.

Por outro lado, a guerra é o ponto fulcral de mobilização interna e externa contra a ditadura, e, portanto, fonte de divisão interna da sociedade, e que acabará por dividir as fileiras do próprio regime. O dogma colonialista que Salazar tinha tentado impor como política de consenso nacional cedia. Em 1957, o Partido Comunista (PCP) estabelece no seu V Congresso, na clandestinidade, a autodeterminação como saída política para as colónias portuguesas. Muito mais reveladora da mudança que se processava dentro das elites tradicionais era a posição de «um reduzido grupo de militares, apoiantes clandestinos da candidatura de Humberto Delgado, que (...) tomou posições mais frontais contra a política colonial, prevendo a inevitabilidade da guerra e condenando, desde o seu início, a forma como o Go-

6 Cf. Cláudia Castelo (1998), «O modo português de estar no Mundo». O luso-tropicalismo e a ideologia colonial portuguesa (1933-1961). Porto: Afrontamento; e o meu inédito (2000), «O Centro de Estudos Políticos e Sociais da Junta de Investigações do Ultramar na construção do assimilacionismo coIonial salazarista», comunicação ao VI Congresso Luso-Afro-Brasileiro de Ciências Sociais (Universidade do Porto). 
verno a desencadeou» (CORREIA, 1999: 159). O chamado Movimento Militar Independente, que participa na tentativa fracassada de golpe de Março de 1959, que ficou conhecido como golpe da Sé, perguntava-se nas páginas da sua publicação clandestina Tribuna Militar, meses antes da rebelião angolana, «»até onde se levará a acção repressiva já iniciada, em Cabo Delgado [- Moçambique -], (...) em Angola (...) e na Guiné?»», antecipando que «»a gente salazarista prepara-se para deixar em África um rasto de sangue, que fará a memória de Portugal ser odiada e banida»» (cit. in CORREIA, 1999: 160).

É possível, portanto, isolar um grupo de militares que «apresentam já uma ideia clara sobre a defesa da paz e do direito dos povos das colónias à independência, linguagem que só muitos anos depois a oposição não comunista viria a adoptar» (CORREIA, 1999: 161). De facto, o Programa para a Democratização da República, concebido no interior da oposição republicana e liberal, apresentado em 1961, poucas semanas antes do início do conflito, admite a necessidade de uma solução política sem discutir a «unidade nacional», mas acabaria necessariamente por evoluir em direcção a um reconhecimento do direito à autodeterminação, como ocorre com as duas candidaturas oposicionistas (Comissão Democrática Eleitoral e Comissão Eleitoral de Unidade Democrática) admitidas à campanha eleitoral de 1969, convocada pelo sucessor de Salazar, num vislumbre de abertura controlada do regime que não produziria resultados satisfatórios. No outro extremo do espectro político, o Governo de Lisboa sentia-se pressionado por boa parte das minorias brancas das suas colónias africanas, tentadas por uma saída à rodesiana ${ }^{7}$.

Os tempos eram, assim, de repolitização da sociedade. Os problemas não eram simplesmente políticos porque a sua natureza imediata assim os apresentava. Tudo se tinha tornado político ao mesmo tempo: os anos da Guerra Colonial e da emigração eram os mesmos da industrialização, das migrações internas e da urbanização, da expansão do sistema escolar e do arranque da emancipação da mulher, da contestação juvenil fora e dentro das fronteiras portuguesas. O chamado marcelismo, enquanto experiência política de aparente renovação (a chamada «evolução na continuidade» de que falava o próprio Marcelo), que lançou muito evidentes esperanças de uma certa liberalização, rapidamente fracassaria enquanto resposta à remobilização política das oposições democráticas, que não cessava praticamente desde 1958 e que vinha provocando a desarticulação dos mecanismos de reprodução sociopolítica do regime, dele afastando gradualmente segmentos importantes dos jovens socialmente favorecidos que passavam por uma Universidade cada vez mais contestária, ou activistas católicos de base que se sentiam os representantes em Portugal dos princípios consagrados no Concílio Vaticano II, contra o imobilismo da hierarquia católica, ou até alguns dos jovens ofi-

7 Rejeitando o processo de autodeterminação iniciado pelo Governo trabalhista de Londres, liderado por Harold Wilson, a minoria branca, dirigida por lan Smith, proclama a independência da Rodésia em 1965, sendo obrigada a deixar o poder à maioria negra, em 1980, na sequência de um novo processo negocial que conduz a uma nova proclamação da independência daquele que, então, se passa a designar como Zimbabwe. 
ciais militares que começavam a achar serem os que verdadeiramente arcavam com todo o peso de uma guerra que não tinha fim político à vista.

Comparemos situações: o Salazarismo fora capaz de superar o ciclo político, que se lhe revelou infernal, de 1958-62: entre o furacão Delgado, em 1958, e as greves estudantis, operárias e camponesas de 1962, ocorreram o asilo de Humberto Delgado na Embaixada brasileira e seu consequente exílio, a fuga de Álvaro Cunhal e de outros elementos da cúpula do PCP da prisão política do Forte de Peniche, em 1960, ou, no mesmo ano, o sequestro do paquete Santa Maria, acontecimentos que asseguraram à oposição portuguesa uma grande publicidade internacional; o início da luta armada em Angola (Fevereiro de 1961) e a consequente tentativa de golpe palaciano dirigida pelas cúpulas militares contra Salazar (a Abrilada de 1961, dirigida pelo ministro da Defesa Nacional, Botelho Moniz); e a condenação diplomática da política colonial portuguesa na ONU; por último, em Dezembro de 1961, fracassava definitivamente a estratégia salazarista em Goa, com a invasão militar indiana recebida sem condenação internacional alguma, situação em nada compensada, verdadeiramente, pelo fracasso da última tentativa militar para derrubar a ditadura (o golpe de Beja, na passagem do ano de 1961 para 1962) preparada antes do MFA de 1973-74. Salazar dirigirá, pela última vez com energia e capacidade inegáveis, o derradeiro processo de renovação política e geracional do seu regime, mobilizando recursos até então inimagináveis para a guerra em África, criando consensos (efémeros, é certo, mas eficazes numa primeira fase) nos grupos sociais dominantes na sociedade portuguesa, conseguindo temporariamente suscitar a ilusão da mudança, de um certo reformismo colonial e de uma modernidade económica, da retoma do controlo sobre o processo político. Salazar assistirá lúcido ainda à comemoração dos 40 anos da sua ascensão ao Poder.

Marcelo, pelo contrário, fracassará. Em 1968-69, anos de tantos embates no mundo capitalista e do Leste socialista (o fracasso da ofensiva norteamericana do Tet e a contestação à intervenção no Vietname; o Maio francês e a aparente recuperação gaullista que acabará com a demissão do general da Presidência francesa; a Primavera de Praga e a sua repressão pela invasão militar do Pacto de Varsóvia; o Autunno caldo italiano de 1969 e a contestação juvenil na RFA), o já velho reformista dos anos '40 e '50 criará, já o sabemos, a ilusão da mudança mas o fracasso tornou-se rapidamente visível quando a última tentativa de renovação do pessoal político do regime - os tecnocratas ligados às políticas da chamada modernização económica e educacional, os protagonistas da ala liberal que deveriam aceitar funcionar como leal oposição no interior das fileiras da ditadura - rejeitam, ao fim de dois/três anos de colaboração, o papel que Caetano deles esperava face às pressões triunfantes dos ultras para que nada de decisivo se alterasse no sistema salazarista. O imobilismo representado pela (nula) revisão da Constituição do Estado Novo, em 1971, e a reeleição de Tomás para a Presidência da República, em 1972, bastaram para eliminar qualquer resquício de esperança que tivesse sido depositada em Marcelo nos primeiros meses (no máximo, nos primeiros dois anos) do seu consulado. A realidade percebida pelos portugueses não estava 
em nenhuma evolução marcelista, mas sim na agudização da repressão política, que atingia e ultrapassava os piores momentos da ditadura, vividos nos anos da Guerra de Espanha (1936-39) ${ }^{8}$, na radicalização das oposições e, acima de tudo, no impasse colonial: nenhuma das grandes, e sangrentas, operações militares dirigidas nos períodos em que Costa Gomes comandou as forças militares em Angola, Kaúlza de Arriaga em Moçambique e António de Spínola na Guiné (1968-73 em todos os casos) haviam eliminado, como prometido, as guerrilhas independentistas. Pelo contrário, a situação na Guiné agravara-se até atingir um ponto sem retorno, que permitira ao PAIGC proclamar unilateralmente, em Setembro de 1973, a independência da República da Guiné-Bissau, reduzindo cada vez mais a presença colonial portuguesa a uma desprotegida faixa litoral. Simultaneamente, o escândalo internacional provocado pelos massacres em Moçambique perpetrados às ordens de Kaúlza, o mais simbólico dos quais o de Wyryamu, permitia acentuar a mobilização internacional contra a ditadura portuguesa, que bem procurava passar despercebida no meio de Estados ocidentais que, na sua maioria, the continuavam a fornecer armas por debaixo da mesa, incumprindo o boicote internacional decretado pelas Nações Unidas.

O mal-estar criado dentro das fileiras militares pela acumulação das sucessivas comissões de dois anos que os jovens capitães eram obrigados a cumprir nas três frentes africanas agravara-se com a demissão de Spínola do cargo de Governador da Guiné (Agosto de 1973), e dele, uma vez mais, e de Costa Gomes do de Vice-Chefe e Chefe do Estado-Maior General das Forças Armadas (Fevereiro de 1974). O último ano do marcelismo será sempre recordado entre a grande maioria dos portugueses, que nada sabiam do grau efectivo de conspiração que se vivia dentro das Forças Armadas, como o do vazio retórico de um cinzento e antiquado catedrático de Direito que, com voz nasal, Ihes falava na TV naquilo que pateticamente decidira chamar Conversas em família, face à expectativa de um pronunciamento militar que pudesse ser lançado, para acabar com a guerra, por oficiais como Spínola ou Costa Gomes, ou para, pelo contrário, arrastar mais recursos ainda para o esforço militar às mãos dos ultras em torno de Kaúlza, como aqueles que se haviam reunido no Porto, em Junho de 1973, no chamado Congresso dos Combatentes...

A fonte de pressão que, por ser mais subterrânea, se revelou, portanto, mais permanente e decisiva era aquela que advinha do cansaço da guerra, quer de uma sociedade metropolitana de onde fugiam os mancebos em idade militar, como dos jovens oficiais que, nos primeiros anos ' 70 , iam já a iniciar, em muitos casos, a quarta comissão de dois anos em território africano. São esses os que se deixam politizar em contacto com muitos oficiais e soldados milicianos que chegavam de Portugal com uma razoável consciência do quadro político de explicação da gue-

8 Cf. dados numéricos in Manuel Braga da CRUz (1988), O Partido e o Estado no Salazarismo. Lisboa: Editorial Presença, p. 83. Sobre a repressão política, cf. o recente MADEIRA, João (coord.); PIMENTEL, Irene Flunser; FARINHA, Luís (2007), Vítimas de Salazar. Estado Novo e violência política. Prefácio de Fernando Rosas. Lisboa: A Esfera dos Livros. 
rra. A estes factores somava-se, em 1973, a percepção militar clara de que a guerra estava já perdida na Guiné. Políticos e militares passaram, então, a temer os efeitos de uma espécie de teoria do dominó, que suporia que o abandono de uma das colónias levaria ao abandono das demais, ao mesmo tempo que muitos oficiais rejeitam a possibilidade de que se viesse a repetir o ocorrido com os seus companheiros depois da invasão de Goa pela Índia, após a qual, relembremo-lo, Salazar optou por responsabilizar exclusivamente os militares pelo facto de não terem obedecido às suas ordens de resistência até à morte. Adicionado a este contexto um conflito de natureza corporativa que funciona como pretexto para a mobilização dos oficiais de patente intermédia que suportavam o peso da guerra, reuniram-se as condições que conduzem ao Movimento das Forças Armadas, que na madrugada de 25 de Abril de 1974 pôs fim a 48 anos de ditadura em Portugal que, precisamente, outros militares haviam instalado no poder.

\section{O CASO PORTUGUÊS: A RUPTURA DEMOCRÁTICA}

Apenas sete meses depois do golpe de Pinochet, os capitães portugueses invertiam numa conspiração militar o sentido do golpe chileno: abrir o caminho à democracia e, seguramente sem o imaginarem, a uma experiência revolucionária absolutamente surpreendente na Europa Ocidental desde o fim da II Guerra Mundial. A tomada espontânea da rua por parte da população logo na manhã de 25 de Abril de 1974, contra todas as expectativas dos militares rebeldes, representa bem uma metáfora do processo de súbita mobilização para a actividade política, que os militares rebeldes não haviam previsto no seu modelo de transformação. Esta mobilização política revelar-se-á, é certo, efémera no médio prazo, mas a verdade é que constituiu o momento de mais forte e massiva participação política da História portuguesa, adquirindo muito rapidamente um tom tão fortemente esquerdizado que contaminará o discurso de todas as forças políticas com actividade legal. Os dois anos que separam o golpe de 1974 da aprovação da Constituição, em Abril de 1976, abrem na História portuguesa a mais completa e típica das conjunturas revolucionárias contemporâneas pela qual o país passou, «[representando] historicamente o mais profundo e ameaçador abalo sofrido por uma oligarquia que desde sempre, em Portugal, reinara incólume e segura de si» (ROSAS, 2004: 138).

Vejamos se é possível estabelecer um legado marcelista como componente política da construção da democracia portuguesa.

\subsection{Movimentos políticos e sociais na transição do Marcelismo para a Democracia}

A conspiração dos capitães de Abril tinha previsto, desde o seu início, um processo de abertura política que permitiria resolver o problema militar e colonial. De 
modo algum, contudo, tinha deliberadamente querido propiciar um processo democratizador que evoluísse em direcção a um quadro revolucionário que alteraria tão radicalmente a paisagem política portuguesa.

Antes de mais, esse quadro criou dificuldades insuperáveis à reorganização do espaço político ocupado pelas elites do regime anterior, o Estado Novo. Ao contrário do caso espanhol, e excepção feita a altos comandos militares, foram raríssimos os casos de destacados membros da hierarquia política derrubada em 1974 que conseguiram criar para si próprios um caminho no Portugal democrático. ${ }^{9}$ A primeira geração de organizações que procuravam recuperar elementos dos níveis intermédios do antigo partido único - a Acção Nacional Popular, versão marcelista da velha União Nacional salazarista - incluiu experiências tão efémeras como o Movimento Federalista Português, logo chamado Partido do Progresso, o Partido Liberal, o Movimento Popular Português ou o Partido Nacionalista Português. Todos parecem ter resultado de uma tentativa artificial de oferecer ao isolado primeiro Presidente da República designado pelo Movimento das Forças Armadas, o general Spínola, um apoio à sua resistência à descolonização e às suas teses pseudofederalistas. Nos arquipélagos atlânticos, os Açores e a Madeira, constituem-se, com especiais ligações a meios políticos norteamericanos, a Frente de Libertação dos Açores (FLA) e a Frente da Libertação da Madeira (FLA$M A)$, que optam por uma inédita postura separatista que se poria em prática, no testemunho de alguns dos envolvidos, se um sistema de modelo soviético se implantasse em Lisboa. ${ }^{10} \mathrm{~A}$ consumação da derrota política de Spínola e a sua demissão em 30 de Setembro de 1974, leva à ilegalização de todos estes grupos, conservando-se somente o Partido da Democracia Cristã, que, impedido de apresentar-se nas eleições constituintes de 1975 , se ficará pelos $0,5 \%$ dos votos nas legislativas de 1976. Eleitoralmente, de resto, a ultradireita que se manteve organizada à margem dos partidos da direita clássica (CDS e PSD) - o que exclui, portanto, os ciclos de viragem mais abertamente populista protagonizados, na última década do séc. XX e na primeira do XXI, por líderes como Manuel Monteiro, Paulo Portas ou Santana Lopes - nunca conseguiu reunir apoios significativos (1,1\% em 1976, 0,2\% em 2005).

Os ambientes assumidamente involucionistas submerger-se-ão desde o Outono de 1974 numa aparente clandestinidade, constituindo grupos armados - o Exército de Libertação de Portugal, o Movimento Democrático de Libertação de Portugal, ou o plano Maria da Fonte, que recrutavam os seus operacionais entre os

\footnotetext{
9 Caso excepcional terá sido o do ministro da Educação Nacional do último Governo da ditadura, Veiga Simão, um tecnocrata «reformista», que é nomeado imediatamente depois do 25 de Abril representante de Portugal nas Nações Unidas, e a médio prazo conseguirá postos ministeriais em Governos socialistas. Adriano Moreira, ministro do Ultramar nos primeiros anos '60, terá que esperar até aos primeiros anos '80 para conseguir um assento na direita parlamentar e, a partir de então, uma forte respeitabilidade democrática.

10 Sobre esta temática praticamente sem investigação que Ihe tenha sido dedicada, cf. Nuno Costa SANTOS (2002), «Um país desfeito no mar», in Grande Reportagem, Setembro 2002, Lisboa, pp. 77-89.
} 
ultras antimarcelistas da fase agonizante da ditadura, autodesignados combatentes do Ultramar. Entre Maio de 1975 e Dezembro de 1976, o «anticomunismo terrorista» de que fala Sánchez Cervelló leva a cabo mais de meio milhar de operações terroristas, das quais resultam, pelo menos, 14 vítimas mortais. Coberta pelo medo dos meios moderados ao avanço do PCP, a sua estruturação «baseouse em quatro componentes: o apoio da hierarquia eclesiástica, cujo epicentro foi o arcebispado de Braga; a ajuda operacional, técnica e económica de Espanha, que além disso proporcionava uma retaguarda segura; a colaboração com os militares contrários ao 25 de Abril que vertebraram todo o movimento, tornando-o eficaz; e, por último, a concordância de todas as forças políticas desde os socialistas até à direita, maioritárias nos distritos do centro e norte do País» (SÁNCHEZ, 1993: 237).

As actuações conspiradoras desta galáxia, que traçam um sombrio «tempo proscrito" (cf. DÂMASO, 1999) de que se falou até agora muito pouco na revisão do período revoucionário português, ajudam-nos hoje a interpretar o comportamento das elites sociais conservadoras, como se Portugal, ou pelo menos a sua metade meridional e os seus centros urbanos, estivessem a viver em 1975 um Grande Terror revolucionário, versão portuguesa. A amplitude das cumplicidades, que vão dos saudosistas da ordem salazarista até ao líder socialista Mário Soares, do embaixador norteamericano, Frank Carlucci (futuro número dois da C.I.A.), até à esquerda moderada militar de tendência terceiromundista, passando pelos prelados católicos e pelas elites intermédias do Norte e Centro rurais, dão-nos um indício de como se terá propagado o medo da tomada do poder político por parte dos comunistas. De uma forma ou de outra, todos confluíram, durante a segunda metade do ano de 1975, na preparação do golpe de 25 de Novembro que afasta definitivamente do poder a esquerda militar próxima do PCP e da extrema esquerda.

No outro lado da barricada política, aparece-nos sempre o PCP, que, apesar da sua nula experiência legal, se revela a mais forte e mais antiga (nascida em 1921) organização oposicionista portuguesa, um caso paralelo ao da França ou da Itália da última guerra mundial, ou ao da Espanha do Franquismo. «O PCP foi o único partido capaz de manter um aparelho clandestino eficaz, facto que determinou a sua hegemonia no movimento de resistência ao longo da maior parte do período [de 1941-74]» (RABY, 1990:16). É o próprio Mário Soares quem entende que «o único partido que foi capaz de resistir à clandestinidade, embora com inúmeras baixas causadas pela impiedosa repressão, foi, nesses anos cinzentos, após a reorganização de 1941, o PCP, apesar da longa prisão do seu principal líder, Álvaro Cunhal, ocorrida em 1949» (SOARES, 1996: 938) A longa clandestinidade, que praticamente cobre toda a história do partido até ao 25 de Abril, juntamente com a solidez da liderança carismática de Álvaro Cunhal, ajudarão a entender um percurso ideológico muito diferente dos seus congéneres europeus, bem como a maior proximidade às teses do PCUS, acentuada com as críticas que, a partir de 1975 , os eurocomunistas italianos e espanhóis, empenhados em esquemas de reconciliação nacional, formulam ao PCP. Os comunistas portugueses, pelo contrário, desde a fuga de Cunhal e de outros nove dirigentes, em 1960, da prisão da 
P.I.D.E. no Forte de Peniche, haviam feito uma autocrítica relativamente tanto à estratégia da «solução pacífica» para conseguir o fim da ditadura, formulada em 1957, como quanto às «ilusões putschistas» alimentadas, havia poucos anos, dentro do partido, mas sobretudo pelos grupos moderados da oposição antifascista desde praticamente o 28 de Maio de 1926. Como sustenta Raby, «embora a Revolução do 25 de Abril de 1974 fosse obra do MFA, a explosão popular que se lhe seguiu ficou a dever-se, em grande parte, ao persistente trabalho político do PCP ao longo das décadas anteriores, às ideias que difundiu», bem como, naturalmente, «ao exemplo de homens como Humberto Delgado, Henrique Galvão e Manuel Serra e ainda à crescente acção da esquerda revolucionária a partir do início dos anos 60» (RABY, 1990: 279).

À saída da ditadura, a capacidade organizativa, sem comparação com as demais forças políticas emergentes, a sua muito importante implantação regional no Sul agrícola e nas cinturas industriais de Lisboa e Porto, atraem ao PCP um número crescente de inscritos (14 mil em Julho de 1974, 29 mil em Outubro de 1974, 100 mil em Março de 1975), muitos dos quais tê-lo-ão eventualmente tomado, de forma precipitada, por um partido de poder. Ora, a tese maioritária entre os observadores contemporâneos do período revolucionário, sobretudo aqueles cuja perspectiva ideológica acabará por se tornar dominante, interpreta o comportamento do PCP como obedecendo a uma estratégia de hegemonia política que passaria previamente pelo controlo das alavancas fundamentais do poder numa sociedade fundamentalmente conservadora que passava então por um transe revolucionário. Tal estratégia suporia integrar numa aliança a maioria dos militares rebeldes de Abril de 1974, a conquista das instâncias do poder formal (governo central e municipal), a hegemonia no movimento sindical e dentro das estruturas unitárias às quais havia dado vida a oposição democrática no consulado marcelista (caso do Movimento Democrático Português/Comissão Democrática Eleitoral, MDP/CDE); por último, o controlo dos meios de comunicação social.

Nas suas linhas gerais, não só o PCP terá fixado efectivamente aqueles objectivos, mas o mesmo também o terão feito, nuns casos mais do que noutros, todas as grandes famílias sociopolíticas, isto é, o PS, a nova direita pósmarcelista, ou a própria extrema esquerda, por separado ou em conjunto. E se é certo que o PCP foi o único dos grandes partidos a participar em todos os seis Governos provisórios constituídos até às primeiras eleições legislativas, apenas num deles o V , dirigido como os três anteriores por um militar que lhe estava próximo, Vasco Gonçalves -, no qual não tinham querido participar socialistas e populares democráticos, conseguiu impor as suas grandes opções; a sua vigência não superou cinco semanas entre Agosto e Setembro de 1975.

$\mathrm{Na}$ avaliação retrospectiva do peso dos comunistas portugueses no processo revolucionário, ocupa um lugar central a aparente surpresa que causou nos observadores moderados os $12,5 \%$ dos votos que o PCP consegue no conjunto nacional em Abril de 1975, o que constitui metade da percentagem que obtém na 
metade Sul do país, e muito abaixo do peso político que reivindicava e se lhe atribuía. Embora fosse possível tentar somar-se-lhe o resultado obtido pelo $\mathrm{MDP} / \mathrm{CDE}$, o seu aliado táctico sempre que não confluía com a extrema esquerda, com os seus $4,1 \%$, a dimensão eleitoral não confirmava a aparente dimensão política, o que, por sua vez, propiciou que no comportamento dos comunistas transparecesse cada vez mais uma explicação leninista do processo revolucionário, no qual eles próprios ocupavam a posição de vanguarda. Uma visão retrospectiva do fenómeno mostra-nos os comunistas, submetidos à pressão radicalizadora da extrema esquerda, tentando a partir de então estender até ao mais longe possível aquilo a que chamavam "as conquistas da Revolução», para logo esperar o refluxo da maré revolucionária e passar à defensiva, quase seguramente conscientes da impossibilidade real de tomar o poder, ou pelo menos sem nunca arriscar qualquer confontação directa, armada.

A médio prazo, os comunistas perderão todas as grandes batalhas políticas em que se empenham, as quais, em última análise, se resumem à tentativa de defender um modelo politicoconstitucional inédito na Europa ocidental, no qual uma sociedade economicamente organizada ainda em moldes capitalistas se declarava constitucionalmente «empenhada na sua transformação numa sociedade sem classes» e em «transição para o socialismo" (arts. $1 .^{\circ}$ e $2 .^{\circ}$ da Constituição da República Portuguesa, texto vigente entre 1976 e 1982). Paradoxalmente, conseguiram ampliar o seu espaço eleitoral nos dez anos seguintes (1976: 14,6\%; 1979:19\%; 1985: 15,6\%), para logo defrontar-se com o impacto negativo da implosão do sistema soviético (1991: 8,8\%; 1995: 8,6\%) que, produzindo consequências em todo o quadro político mundial e na evolução da esquerda europeia em particular, trouxe efeitos di lacerantes para o interior do PCP.

O Marcelismo, como última fase da ditadura, e o fulgor revolucionário que se the seguiu abriu espaço político às muito variadas famílias da extrema esquerda portuguesa. A conquista de um enraizamento significativo entre os jovens, sobretudo os estudantes das camadas médias e altas urbanas, e a sua grande capacidade de atracção de elementos populares automobilizados fora da área do PCP, apesar da sua escassa implantação operária, reserva-lhe um papel central na radicalização do processo revolucionário. Como ocorre na generalidade dos casos europeus, a sua origem pode ser situada numa cisão comunista, aquela que em 1963 Francisco Martins Rodrigues protagoniza dentro do PCP, criando a Frente de Acção Popular. Mas na década seguinte tentaram consolidar-se cinco grandes correntes.

Os maoístas em primeiro lugar. Os mais constantes, criam em 1964 o Comité Marxista-Leninista Português, que, mudando sucessivamente de designação e de modelo de organização, confluiu na mais bem sucedida das entidades políticas deste sector, a União Democrática Popular, que detém autonomamente um assento parlamentar entre 1975 (0,8\% dos votos) e 1983 (1,4\% nas eleições de 1980), e tornará a possuir uma representação parlamentar mínima ao confluir com trotskistas e radicais de esquerda, em 1999, numa das mais bem sucedidas 
experiências europeias de renovação deste sector político, a da criação do Bloco de Esquerda (BE: 2,4\% dos votos nas legislativas de 1999, 2,8\% em 2002, 6,4\% em 2005).

No campo variadíssimo dos que reivindicavam uma inspiração na via chinesa, emergem organizações prioritariamente hostis ao PCP, com um fortíssimo poder de atracção nos ambientes estudantis da burguesia, e que, mais do que noutros casos, se esvaziaram muito rapidamente no final do período revolucionário, numa diáspora política e profissional, em direcção aos grandes partidos moderados do sistema, o mundo empresarial, a universidade ou os media. O mais apelativo terá sido o Movimento Reorganizativo do Partido do Proletariado (MRPP) que resulta, em 1970, da Esquerda Democrática Estudantil. Juntamente com outras organizações $M L$, travará batalhas constantes contra o «revisionismo dos socialfascistas do PCP», constituindo uma pequena frente esquerdista abertamente oposta aos militares do M.F.A..

Nas suas margens, emergem organizações que enveredam pela luta armada durante a ditadura, com escassíssimos resultados: a Liga de Unidade e Acção Revolucionária (LUAR, criada em 1967), as Brigadas Revolucionárias (criadas em 1971) que se fundem com o Partido Revolucionário do Proletariado (PRP/BR) em 1973, que opta por permanecer clandestino depois do 25 de Abril. O impacto simbólico de algumas das suas acções, não obstante, terá levado o PCP, na última fase da Guerra Colonial, a criar um efémero braço armado, a Acção Revolucionária Armada (1970-72), que se limita a operações de sabotagem militar. Nenhum dos dois fenómenos terá ligações com a única e breve experiência de luta política armada em Portugal desde finais dos anos '70, as Forças Populares 25 de Abril, desmanteladas em 1984, tendo como referência um militar de Abril politicamente inclassificável, Otelo Saraiva de Carvalho.

A componente trotskista, muito débil, desta esquerda é uma das últimas a comparecer aos debates políticos da oposição mais radicalizada contra a ditadura. O seu sector maioritário constituirá os Grupos de Acção Comunista em 1972, a Liga Comunista Internacionalista no ano seguinte, e consolidar-se-á no Partido Socialista Revolucionário (1978), que revelará grande adaptabilidade ideológica nos anos '90, até conseguir atrair descontentes dos dois grandes partidos da esquerda portuguesa e idealizar o BE, cuja identidade ideológica está sobretudo marcada pelo legado do PSR e pelos impulsos políticos de uma nova geração de activistas, grande parte dos quais oriundos do mundo universitário, que tem empurrado o papel do $B E$ mais para um terreno mais semelhante àquele que, no âmbito daquelas que aparecem descritas como grandes questões de civilização, desempenhava o Partido Radical italiano nos anos '70 e ' 80 , do que propriamente para experiências semelhantes às da Refundação Comunista italiana ou da extrema esquerda francesa (LCR e LO) dos últimos anos.

Por último, a franja eleitoralmente mais numerosa da extrema-esquerda do período revolucionário (representará $2,1 \%$ dos votos em 1975, 1,2\% em 1976) foi a 
que reuniu jovens católicos progressistas e activistas sindicais que estiveram na origem quer do Movimento de Esquerda Socialista, quer da Frente Socialista Popular, uma cisão pela esquerda do PS do final de 1974. Os primeiros, ao ingressar nas fileiras socialistas em finais da década (entre eles, o Presidente da República dos mandatos 1996-2006, Jorge Sampaio), farão o percurso inverso dos activistas da segunda, a única entre todas estas organizações que colaborará frequentemente com o PCP. No momento crítico (Agosto/Setembro) do Verão Quente de 1975 , o ponto de mais forte radicalização à esquerda do PCP, estas organizações, juntamente com MDP/CDE, os trotskistas, a LUAR e o PRP/BR, confluem com os comunistas numa efémera Frente de Unidade Revolucionária.

Representando eleitoralmente, e em toda a sua variedade, 4 a $5 \%$ do eleitorado nas eleições de 1975 e 1976, o canto do cisne da extrema esquerda acabará por ser a candidatura presidencial de Otelo Saraiva de Carvalho, que em Julho de 1976 reúne $16,7 \%$ dos votos frente ao triunfante candidato conjunto dos socialistas e da direita, Ramalho Eanes.

No terreno eleitoral, a chamada esquerda sociológica passará a estar, na sua grande maioria, representada no PS, que se configura organizacionalmente como um amplo comité eleitoral, crescentemente sustentado no poder local. Os socialistas portugueses, seguindo em boa parte o modelo dos seus companheiros franceses da SFIO dos anos '40, '50 e '60, ao não poder reivindicar uma forte raiz operária, são herdeiros de uma tradição republicana burguesa que se aglomera em torno de organizações efémeras de notáveis nos anos ' 40 e ' 50 , evoluindo em direcção a formas mais assumidamente socialistas como a Acção Socialista Portuguesa (criada em 1964, admitida em 1972 na Internacional Socialista) e, só em 1973, um Partido Socialista. Entre o PS e a ASP, não mais de 190 activistas assegurariam, entre 1964 e 1974, a presença política deste sector na vida portuguesa. ${ }^{11}$ A figura de Mário Soares (Primeiro Ministro em 1976-78 e 1983-85, Presidente da República em 1986-96, de novo candidato presidencial em 2005-06, desta vez humilhantemente derrotado ${ }^{12}$ ) resulta imprescindível à interpretação do fenómeno, e insubstituível na liderança socialista na primeira década da democracia.

No período marcelista, os socialistas, ainda do tempo da ASP, haviam-se «[demarcado] do PCP e [adiantaram-se] como interlocutor privilegiado da esperada «abertura» do regime», posição reforçada pela autorização que Marcelo concede ao regresso (1970) de Soares da deportação a que Salazar o havia condenado em S. Tomé e Príncipe. No «rescaldo das eleições de 1969», contudo, dá-se a «rotura»: «o PS radicaliza o seu discurso, Mário Soares é novamente impedido de entrar no

11 António Arnaut fala em algo «»mais de 100 pessoas directamente comprometidas»» (cit. in MARTINS, 123-24).

12 Soares, apoiado por um governo maioritário socialista, dirigido por José Sócrates, não conseguiu mais do que $14,3 \%$ dos votos, contra $20,7 \%$ do seu camarada socialista Manuel Alegre, que se candidatou contra a vontade da direcção do PS. Cavaco Silva ganhou tangencialmente a eleição à primeira volta, com $50,6 \%$ dos votos expressos. 
país e, em 1973, PS e PCP estabelecem um acordo de cooperação política» (ROSAS, 2004a: 16 e 22), em grande parte na esteira no Programme Commun de la Gauche francesa, assinado em 1972 depois de 25 anos de ruptura.

Desencadeado o processo democratizador, o PS autopercepciona-se, um pouco à italiana, como o parceiro mais débil da esquerda portuguesa, temendo a secundarização a que o PCP gostaria de o votar, mas desde o início de 1975 que o seu papel se torna central na configuração do processo democratizador português. A demissão de Spínola (Outubro de 1974) e a consequente viragem involucionista das forças conservadoras, juntamente com a debilidade organizativa da direita política, tinha a sua imagem especular no impulso revolucionário das reivindicações sociais e na forma como os comunistas demonstravam a sua capacidade para ocupar gradualmente os espaços políticos e institucionais deixados vazios pela implosão das estruturas do Estado autoritário. Livre da sua ala mais radical no Congresso de Dezembro de 1974 (saída dos socialistas populares de Manuel Serra), o PS de Soares, como frente de resistência anticomunista, passa então a atrair os apoios das elites e poderes tradicionais, empenhando-se em combates frontais com o PCP em temas como a rejeição da unicidade sindical que os comunistas querem impor, ou a sua presença julgada excessiva na direcção dos meios de imprensa. Desde a vitória eleitoral nas constituintes de Abril de 1975 que os socialistas se tornam, numa lógica muito típica da Guerra Fria, na peça fundamental na estratégia normalizadora das potências ocidentais, os norteamericanos em primeiro lugar, juntamente com a Internacional Socialista, e muito particularmente o SPD alemão, o que Ihes permite pressionar decisivamente na direcção do afastamento dos militares próximos ao PCP do Governo, negando-se a participar neste entre Julho e Setembro, e empenhando-se eficazmente nos manejos secretos que conduzem ao golpe de 25 de Novembro e à viragem anticomunista que definitivamente se produz nesse momento.

Quase a partir do nada, o PS encontra-se, em 1975, com uma presença transversal na sociedade. Outorgam-Ihe a sua confiança a pequena burguesia urbana dos serviços e a rural, os operários menos organizados (particulamente no Norte), os segmentos ideologicamente independentes do mundo profissional liberal, com uma concentração eleitoral típica dos movimentos modernizadores da sociedade portuguesa, isto é, no litoral e nas cidades. São estes, conjunturalmente apoiados durante o período revolucionário por todos quanto confluíam no PS para «barrar o caminho ao PCP», que the fazem reunir $37,9 \%$ dos votos em 1975 e $35 \%$ um ano mais tarde.

O crescimento e a consolidação do PS resulta também da incapacidade, ou a impossibilidade prática, do mundo católico em formar uma ampla frente política democrata cristã como as constituídas em Itália ou na Alemanha do pósguerra. Resulta curiosa, neste sentido, a coincidência entre dois processos democratizadores tão distintos como o português e o espanhol. O carácter católico tão «ideologicamente intrínseco» do regime salazarista, como definiu Braga da Cruz (1980: 17), a 
confessionalização assumida de todas as suas políticas sociais - na educação em primeiro lugar, na saúde e na assistência social - , das organizações de doutrinamento de massas (Mocidade Portuguesa, masculina e feminina, Legião Portuguesa, Organização das Mães para a Educação Nacional, organismos corporativos, Fundação Nacional para a Alegria no Trabalho), de todas as formas de propaganda e de censura, em suma, das dimensões institucionais do regime e da versão da própria identidade nacional que este tentou impor, dificultaram enormemente a emergência de quaisquer manifestações de autonomia ideológica do mundo católico perante o regime.

Comportamentos dissidentes isolados como os do padre Abel Varzim ou do bispo do Porto, em 1958, vêem-se reforçados com o Concílio Vaticano II. Abre-se por aí um caminho à relativamente pouco numerosa, mas muito simbólica, corrente dos católicos progressistas que, nos anos ' 60 , se reúnem em redor da revista $O$ Tempo e o Medo, da cooperativa cultural Pragma, dos GEDOC (Grupos de Estudo, Documentação, Intercâmbio, Experiências), e ganham protagonismo na Liga Operária Católica e nas Juventudes Escolar e, sobretudo, Operária Católicas. Os mais avançados partilham com activistas da oposição democrática, entre os quais estão muitos comunistas, as listas eleitorais das Comissões Democráticas Eleitorais de 1969 e 1973, e protagonizam nos últimos anos da ditadura confrontos com o regime que a este resultam particularmente irritantes pela identidade católica dos opositores. Depois de 1974, boa parte deles milita já no PS ou estão politicamente dispersos por alguma extrema esquerda (MES), muito mais raramente no PCP, através do seu activismo sindical.

A maioria do activismo católico e a hierarquia da Igreja permanecem nesta conjuntura, essas sim, fiéis a uma visão reaccionária do mundo, que vê com verdadeiro terror a contestação moral e ética que, durante o período revolucionário, se produz contra o seu peso na vida quotidiana e na formação de opinião, ao mesmo tempo que sofre a denúncia da política de compromisso com a ditadura. Embora os protagonistas do novo regime democrático e das forças da esquerda tradicional (comunistas e socialistas) tenham aparentemente usado de cautelas extremas para evitar cair na confrontação aberta entre Estado e Igreja como a que se desencadeou na Primeira República (1910-26), o ímpeto revolucionário, a laicização rápida das práticas sociais, em revelador contraste com o crescente pluralismo das crenças que se acentua com o fenómeno do afluxo dos excolonos de África, crispa os integristas e o segmento mais involucionista da hierarquia (dioceses do Norte, e em particular o arcebispado de Braga nos tempos de D. Francisco Maria da Silva), que se misturam nas movimentações da extrema direita, tornando-se a chave da luta anticomunista do Verão de $1975 .{ }^{13} \mathrm{~A}$ Igreja mobilizar-se-á regular e eficazmente em todos os períodos eleitorais, embora o faça sobretudo de forma

13 Sobre toda a questão, cf. SÁNCHEZ, 1993, DÂMASO, 1999, e o estudo de jornalismo de investigação Günther WallRAfF (1976), A descoberta de uma conspiração: a acção-Spínola, trad. port.. Amadora: Bertrand. 
negativa, contra o PCP e, quando a direita se apresenta unida logo no final dos anos ' 70 , o PS. O período mais intenso deste comportamento termina com as eleições presidenciais de 1986, nas quais os dois candidatos que se defrontam (Mário Soares e Freitas do Amaral) acrescentam à sua identidade política uma contraposição laica/confessional, e teve um ressurgimento em 1998 e 2007 com os referendos à discriminalização do aborto. ${ }^{14}$

Um dos dois grandes partidos da direita democrática, o Centro Democrático e Social (CDS), tenta apresentar-se logo no período revolucionário sob uma identidade democrata cristã, mas o seu escasso peso eleitoral - 7,7\% em 1975, 16\% em 1976 - no conjunto das direitas eleitorais impede que a Igreja, como faz noutros casos nacionais, aposte definitivamente numa única opção política. A reforçar estes obstáculos iniciais, as tentativas de organizar um sindicalismo cristão não se conseguiram consolidar. O CDS ofereceu, contudo, a elementos jovens do marcelismo uma via possível de reciclagem democrática, embora tenha conservado um tal elitismo sociológico, concentrado nos meios tradicionalistas de Lisboa e do Norte e Centro do país, que dificilmente superaria o invento político mais bem sucedido da direita, o Partido Popular Democrático (PPD), rebaptizado Social Democrata (PSD) em 1976.

O PPD, que, ao contrário do CDS, é convidado a participar em todos os Governos provisórios do período revolucionário, e que, como o PS, rejeitará ingressar em apenas um deles (o 5..$^{\circ}$, dirigido durante uma parte do Verão de 1975 por Vasco Gonçalves), funcionou rapidamente como elemento aglutinador das forças conservadoras e populistas, socialmente não elitistas e que maioritariamente não se autodefiniam como confessionais. Uma parte dos seus fundadores, além disso, podiam, uma vez mais em contraste com o CDS, revindicar um papel publicamente destacado na oposição final à ditadura, ao ter constituído a chamada Ala Liberal dos deputados oficialistas em 1969-72, que rompe abertamente com Marcelo Caetano ao comprovar a sua falta de vontade de abertura. Juntam-se-lhes alguns tecnocratas marcelistas (com particular êxito político e institucional no decénio cavaquista que se abre em 1985), católicos moderados, os elementos das elites tradicionais do Norte e no Centro que não se reviam no CDS, e destacados representantes dos excolonos de África, que afluem a Portugal em 1974-76. O PPD reúne, assim, em $1975,26,4 \%$ dos votos e, um ano depois, $24,4 \%$, consolidandose definitivamente como a força dominante da direita portuguesa ao hegemonizar a Aliança Democrática que ganha as eleições de 1979 e 1980 e, sobretudo, ao ser o primeiro partido da história da democracia a conseguir a maioria absoluta dos votos e dos lugares parlamentares (1987 e 1991).

14 Para sínteses sobre «A Igreja e os católicos» no período marcelista, cf. sob este título José BARRETo (2004), in Fernando Rosas; Pedro Aires OliveIRA (coords.), A transição falhada. O Marcelismo e o fim do Estado Novo (1968-1974). S.I.: Círculo de Leitores, pp. 137-70, e sobre a «Igreja na Revolução em Portugal (1974-82)», com a qual não estou, contudo, substancialmente de acordo, cf. com aquele título artigo de Luís Salgado de MATOS, in BRITO, 2001. 
O país eleitoral que o sufrágio desenha, pela primeira vez na História contemporânea, e que conserva até hoje a sua distribuição no espaço, aparece claramente dividido em duas metades, separadas por uma linha transversal que passa algures a Norte do Tejo, entregando à direita o Norte e Centro da pequena e média propriedade juntamente com as ilhas (com a excepção dos Açores depois das eleições regionais de 1996), e à esquerda o Sul da grande propriedade e de estrutura industrial pesada nascida nos anos ' 50 , juntamente com pontos significativos do litoral Norte e Centro, como, na grande maioria das eleições legislativas e presidenciais, a área metropolitana do Porto, as zonas industrializadas do Minho e a região de Coimbra. Apesar do fenómeno da concentração eleitoral nos grandes partidos do centro esquerda (PS) e do centro direita (PSD) - 64,3\% em 1975, $50,6 \%$ em 1985 (o seu ponto mais baixo), 79,7\% em 1991 (o seu ponto mais alto), 73,7\% em 2005 -, que alternam rotativamente no poder, a pluralidade do sistema representativo, numa paisagem política de que estão ausentes partidos de âmbito regional, garante, ainda hoje, a presença parlamentar a cinco candidaturas distintas (uma menos que em 1975, uma mais que no período 1983-85 e 1991-99): PS, PSD, coligação PCP/Verdes, CDS, BE.

Outra componente do sistema sociopolítico é, evidentemente, o movimento sindical. Historicamente débil em Portugal, uma sociedade com pouca tradição sindical, em cujo tecido económico predominava uma economia agrária de baixíssimos conteúdos tecnológicos, ao lado da qual vegetava um aparelho industrial que não acabaria de mudar estruturalmente a economia até ao segundo pósguerra mundial, o movimento sindical manteve, até ao derrube da República liberal, uma hegemonia anarcosindicalista, produtora de organizações confederais como a União Operária Nacional (U.O.N., 1914-18) e a Confederação Geral do Trabalho (C.G.T., criada em 1919 e definitivamente ilegalizada em 1927, assumindo uma acção rigorosamente clandestina desde o fracasso da greve geral de 1934). Esta última teria conseguido em 1925, na sua fase mais tardia de acção legal, a sindicalização de qualquer coisa como $21 \%$ dos trabalhadores activos na indústria e nos serviços, dos quais haveria que retirar provavelmente cerca de 1/7 que corresponderiam a trabalhadores rurais. ${ }^{15}$

As estruturas sindicais constituídas pelo regime salazarista a partir de 1933, e que comunistas e católicos progressistas começam a penetrar com evidente êxito nos finais dos anos ' 60 , constituíram, efectivamente, uma herança natural para os activistas que pretendiam, a partir do 25 de Abril, construir um movimento sindical que participasse activamente nas transformações revolucionárias. O grande elemento de continuidade formal, embora evidentemente não de conteúdo, resultava do facto de

15 Cf. dados em João FreIRE (1992), Anarquistas e operários. Ideologia, ofícios e práticas sociais: o anarquismo e operariado em Portugal, 1900-1940. Porto: Afrontamento, pp. 204-209; Ramiro da CosTA [1979], Elementos para a História do movimento operário em Portugal, 1820-1975, 1. ${ }^{\circ}$ vol. (1820-1929). Lisboa: Assírio \& Alvim, pp. 94 e 100; e Maria Alice SAmARA (2003), Verdes e Vermelhos: Portugal e a Guerra no ano de Sidónio Pais. Lisboa: Notícias Editorial, pp. 83-84. Agradeço aqui a ajuda de Silvestre Lacerda na reunião e interpretação destes dados. 
a Primavera Marcelista dos primeiros anos do governo de Caetano ter permitido, graças à aprovação de legislação (cf. Decreto-Lei n. ${ }^{\circ} 49.058$, de 14.6.1969) que relaxava o controlo directo exercido pelo Governo sobre as direcções sindicais, permitindo a eleição, nos anos imediatamente subsequentes, de muitos activistas comunistas e católicos progressistas para os orgãos directivos de alguns dos sindicatos mais representativos. As Reuniões Intersindicais que congregam desde 1970, de forma semiclandestina, as direç̧ões de uma vintena de sindicatos constituem a experiência fundadora da Intersindical Nacional (IN). ${ }^{16} \mathrm{O}$ processo de desmantelamento daqueles a que a ditadura chamava os Sindicatos Nacionais, começa com aquilo que a IN definiu em 1974 como a sua «iniciativa autónoma de democratização» daqueles (cf. CGTP- IN-20 anos...), propondo-se desde logo controlar o seu património. A partir da viragem à esquerda do Outono de 1974, com a demissão de Spínola, desencadeia-se aquilo que habitualmente se descreve como tendo sido a «estratégia maximalista e afinal suicidária do PCP» (FERREIRA, 1994: 165) na questão da unicidade sindical, em grande parte seguida de acordo com os activistas católicos do mundo sindical, e que pretendia consagrar legalmente, em Abril de 1975, o desdobramento de organismos sindicais representativos do mesmo sector profissional. Os comunistas e os seus aliados defrontam-se então com os socialistas, que beneficiam do apoio conjuntural de alguma extrema esquerda, que perdem a batalha legal em 1975 para logo ganhá-la na redacção definitiva do texto constitucional aprovado em 1976, o qual consagrava «a liberdade da constituição de associações sindicais a todos os níveis» (art. 57. ${ }^{\circ}$ ).

Com a segunda vitória eleitoral socialista, em Abril de 1976, e a constituição do primeiro Governo Constitucional, «é como partidos do poder (e consequentemente do Estado) que PS e PSD", com a colaboração activa do CDS, coordenam uma estratégia de criação de sindicatos alternativos aos agrupados à volta da $\mathrm{IN}$, com o apoio financeiro e logístico das fundações políticas alemãs (a socialdemocrata Friedrich Ebert, a liberal Naumann, e a democrata cristã Adenauer) com as quais estabelece laços orgânicos (cf. FERREIRA, 1994: 160), de forma muito similar ao que ocorreu quase contemporaneamente em Espanha. Nasce assim, a partir de cima, o movimento Carta Aberta que reúne uma centena de direcções sindicais e que rompe, em Agosto de 1976, com a IN no processo de convocatória do Congresso de Todos os Sindicatos (Janeiro de 1977), no qual a IN se transforma na Confederação Geral dos Trabalhadores Portugueses (CGTP- IN).

Da Carta Aberta nascerá em Outubro de 1978, a União Geral dos Trabalhadores, e a constituição da segunda central sindical permite perceber os contornos finais do modelo sindical português. Nos anos seguintes, consolida-se uma relação

16 Sob a minha orientação, Hélder Marques desenvolve desde 2004 na Faculdade de Letras da Universidade do Porto uma investigação em torno destas questões, em grande parte devedora de materiais recolhidos, em parte também por ele, na Universidade Popular do Porto - cf. UNIVERSIDADE POPULAR Do PORTO (2006), «O Centro de Documentação e Informação sobre o Movimento Operário e Popular do Porto (CDI) da Universidade Popular do Porto», in Loff, Manuel; PEREIRA, Maria da Conceição Meireles (coords.) (2006), Portugal, 30 anos de Democracia (1974-2004). Porto: Editora da Universidade do Porto, pp. 287-94. 
de forças que favorece uma confederação (CGTP-IN) de maioria comunista, partilhada com sectores católicos progressistas, socialistas de esquerda e elementos da extrema esquerda, que assegurou até meados dos anos ' 80 a afiliação de praticamente três quartos dos sindicalizados; e uma confederação socialista-liberal-cristã (UGT), sobretudo representada no terciário, agrupando um quinto dos filiados nos sindicatos portugueses. Neste sentido, mas apenas neste, reproduz-se de alguma forma um modelo semelhante ao que até aí dominava nos demais países latinos da Europa Ocidental nos anos '70 e até meados dos ' 80 . Em finais desta ú ultima década, o redimensionamento do predomínio da CGTP-IN (57\% dos sindicalizados em 1986-90, contra 33\% da UGT, segundo CERDEIRA; PADILHA, 1990) ajudou a aproximar ainda mais o caso português da situação francesa, italiana ou espanhola.

No caso português, acrescenta-se-lhe uma outra herança formal do sistema corporativo, isto é, uma taxa de sindicalização sensivelmente superior à média europeia, que um estudo de 1969 fixava em 59\%. Outra investigação governamental no início dos anos '90 (CERDEIRA; PADILHA, 1990), traçava uma curva irregular na taxa de sindicalização que teria baixado no período revolucionário (média de $52,4 \%$ em 1974-78), subindo nos primeiros anos de competição entre as duas centrais sindicais (1979-84: 58,8\%), e voltado a baixar até aos 52,6 \% de 1985-86, para logo aproximar-se, por baixo, dos mais altos níveis europeus (1989/90: 42\%, ou nunca mais de $35 \%$ segundo um trabalho académico inédito de José Barreto). Essa taxa, segundo o mesmo estudo, estaria próxima de $100 \%$ em sectores como a banca e seguros, muito elevada entre os funcionários da Administração Pública, mas tendia a baixar muito significativamente nos anos ' $80 \mathrm{em}$ quase todos os demais sectores, sobretudo serviços privados e indústria. O número de sindicatos teria subido dos 328 corporativos recenseados em 1973, no final do Marcelismo e da ditadura, até aos $372 \mathrm{em}$ finais dos anos '70 (cf. VALENTE, 1996), número máximo que tenderia a partir de então, também ele, a baixar. ${ }^{17}$

O derrube de um regime autoritário que se preocupara em esfriar o ambiente político do primeiro quarto de século, isto é, em despolitizar os comparativamente restritos segmentos da população portuguesa que se empenhavam em actividades cívicas ao longo da Primeira República, tinha sido obra do Movimento das Forças Armadas (MFA), que emergiu de uma instituição militar de dimensões excepcionalmente inflacionadas no contexto do esforço bélico que se levava a cabo em África. A leitura anteriormente proposta de um processo político democratizador que se escapa das mãos dos conspiradores militares triunfantes em 25 de Abril de 1974 não contradiz a tese de Sánchez Cervelló que vê «duas características essenciais da Revolução portuguesa: a hegemonia militar e a subalternidade civil, à margem dos modelos políticos que para o futuro do país projectavam uns e outros" (SÁNCHEZ, 1993: 185).

17 Sobre «O movimento operário e sindical (1970-76): entre o corporativismo e a unicidade», cf. o artigo com este título de José Carlos VALENTE, in BRITO, 2001. 
O MFA constituiu na sua origem «uma metamorfose da instituição militar para esta se insubordinar e derrubar o regime ditatorial, e para gerir o complexo e convulsivo período seguinte", devendo para tanto " "mobilizar" um corpo de intervenção especial politico-militar» (FERREIRA, 1993: 224). Uma das características essenciais da instituição castrense, a cadeia de comando, viu-se crescentemente interferida por uma lógica representativa e democratizadora que rapidamente produziria rupturas no modelo que implicitamente se tentara construir de uma transição para a democracia sob tutela militar.

À margem de estruturas mais facilmente tipificáveis como a Presidência da República, que foi ocupada por três militares - Spínola e Costa Gomes de modo provisório, Ramalho Eanes já legitimado pelo voto popular — até à eleição presidencial de 1986, ou os Governos Provisórios que se constituíram entre 1974 e a tomada de posse do primeiro Governo saído das eleições legislativas de 1976, a oficialidade levada ao poder constituiu inicialmente uma Junta de Salvação Nacional, substituída por um Conselho da Revolução depois do fracasso do golpe de 11 de Março de 1975, transformado no período constitucional no órgão de fiscalização da constitucionalidade das leis e que desaparecerá definitivamente na primeira reforma do texto fundamental em 1982.

Com ambos os órgãos estabeleciam-se entidades de comando politicomilitares que, dadas as circunstâncias excepcionais do momento, quebravam as regras de precedência, promoção e hierarquia militar em geral. A introdução de uma lógica democrática, para não dizer revolucionária, acentua-se claramente com a criação, em Novembro de 1974, de assembleias de delegados do MFA - uma por cada ramo das Forças Armadas e uma quarta que congregava representantes de todas elas -, uma percentagem significativa dos quais era eleita. Em Março de 1975 introduz-se nestas assembleias a representação dos soldados, o que acentuava ainda mais um processo de osmose entre instituição militar e sociedade politizada, numa fase de «incorporación forzosa de muchos jóvenes que habían desertado por motivos políticos, (...) gente fuertemente politizada que acabó ayudando a la generalización de la indisciplina» (SÁNCHEZ, 1996: 250-51).

A dimensão da metamorfose das Forças Armadas portuguesas resulta ainda mais visível ao instituir-se o MFA como verdadeira força de acção sociopolítica de aceleração das transformações democráticas. Neste sentido, o MFA firmou com os partidos políticos dois pactos formais anteriores às eleições constituintes de Abril de 1975 e às legislativas de Abril de 1976. Reconheceu-se-lhe a prioridade política na tomada de posições no processo de descolonização, motivo desencadeador do golpe militar e terreno no qual, até à demissão de Spínola, a divisão interna do MFA era particularmente evidente. Tudo o que fosse referente à política de Defesa e aos aspectos de organização do aparelho militar era da sua competência exclusiva

A grande maioria das actuações mais especificamente sociopolíticas do MFA eram realizadas por dois instrumentos de actuação paramilitar. O primeiro era de 
aparência exclusivamente militar: o Comando Operacional do Continente (COP$\mathrm{CON}$ ), formalmente encarregado de intervir em «situações de ameaça à paz e tranquilidade públicas", coordenando forças militares e policiais (cf. Decreto-Lei n. ${ }^{\circ}$ 380/74, 8 de Julho), comandado por Otelo Saraiva de Carvalho, o qual conseguiu assim uma plataforma fundamental para desenvolver o seu papel no período revolucionário. A actuação do COPCON em todo o tipo de movimentos sociais desde a ocupação de terras e casas até à socialização de fábricas, revelou, apesar do seu carácter frequentemente incoerente e irregular, uma aproximação aos procedimentos mais típicos de boa parte da extrema esquerda que a si atrairia o próprio Otelo nos anos seguintes. Pelo contrário a criação da $5 .{ }^{a}$ divisão do Estado-Maior Geral das Forças Armadas (cf. Decreto-Lei n. ${ }^{\circ} 400 / 74,29$ de Agosto), com funções muito amplas no campo da chamada Acção Psicológica (terminologia herdada da Guerra Colonial), informação, divulgação e doutrina «sócio-militar», e em particular da sua Comissão de Dinamização Central (CODICE), propiciou a organização de Campanhas de Dinamização Cultural, que se levaram a cabo entre Novembro de 1974 e Agosto de 1975 nas regiões do interior Norte e Centro do país, juntamente com os Açores, territórios nos quais, durante boa parte do período revolucionário, a soberania das decisões do novo poder saído da Revolução não foi efectivamente exercida. A actuação de milhares de militares e voluntários civis teve dimensões educativas, como a alfabetização, sanitárias, de obras públicas e de consciencialização política, que pretendiam levar a Revolução até onde quase nada parecia ter mudado. O recrutamento dos seus dirigentes e a caracterização política dos protagonistas das suas acções aproximou a $5 .^{\circ}$ divisão da actuação da esquerda revolucionária (PCP e extrema esquerda), e contribuiu para a politização assumida do MFA.

Reflectindo a divisão da sociedade no período de mais forte politização, o MFA transformou-se na instância em cujo seio se dirimiram duas concepções contrapostas de construção do sistema democrático. Por um lado, os militares do Grupo dos Nove e os sectores castrenses conservadores que os apoiam convergem tacticamente com o PS e a direita política e militar, e preparam a derrota da versão radical do projecto revolucionário que, do outro lado, um sector significativo do MFA havia assumido, pretendendo introduzir (ou não se opor a) alterações estruturais na organização capitalista da economia e da sociedade. É a primeira concepção que triunfa com o golpe de 25 de Novembro de 1975, assegurando a transição de um sistema de poder revolucionário inevitavelmente caótico e criativo para um modelo democrático formal, parlamentar, temporariamente sob tutela militar. Definitivamente derrotada saía a concepção, fortemente original no quadro dos movimentos castrenses contemporâneos, que pressupunha a construção de um modelo político e social que se definia como socialista - adjectivo que, não obstante, andava então nas bocas de praticamente todos os agentes políticos -, de legitimidade revolucionária e não exactamente eleitoral, conduzido por uma vanguarda militar. Esta concepção, que parecia hegemónica nas assembleias do MFA da Primavera e do Verão Quente de 1975, cuja lógica era partilhada pelos 
sectores mais próximos do PCP e da extrema esquerda, e que tinha, em campos bem separados e definidos, em Vasco Gonçalves, por um lado, e em Otelo e no COPCON, por outro, protagonistas e instrumento, sai definitivamente derrotada em 25 de Novembro.

\subsection{A ruptura social}

Nos dois anos do chamado Período Revolucionário (1974-76), e sob o impulso dos movimentos sociais, procede-se ao quase eufórico desmantelamento do Estado autoritário, e em boa medida do próprio autoritarismo tão óbvio em sociedades com características como a portuguesa. Em alguns campos, o contexto social é praticamente libertário, já que, uma vez esvaziado de conteúdo o sistema de poder anterior, não se chega a edificar um alternativo.

Neste terreno, a interpretação do processo de mudança radical que se desencadeia em tão pouco tempo na sociedade portuguesa centrou-se quase sempre, tudo indica que excessivamente, em esquemas explicativos que reproduzem verdadeiras teorias da conspiração de lógicas muito semelhantes àquelas que presidem às explicações que, em tantos outros casos de mudanças revolucionárias, as elites tradicionais - vítimas da mudança, desapossadas do poder - subscrevem. O avanço da pouca investigação que se tem produzido no nosso país em torno dos movimentos sociais ocorridos e/ou organizados neste período tem permitido relativizar - só não sabemos se também na leitura do público em geral — uma explicação do período revolucionário, daquele que ainda hoje se gosta de designar por PREC (Processo Revolucionário em Curso), centrada no papel sobreavaliado dos directórios dos partidos revolucionários (PCP e extrema esquerda), ou no de uma dezena de dirigentes da esquerda militar, aos quais se teriam contraposto os directórios dos partidos democráticos ou moderados (PS e direita parlamentar), aliados a outra dezena de dirigentes militares moderados e a uma rede ainda pouco estudada de forças internacionais, globalmente representativas do Ocidente. Esta matriz de explicação é em tudo coerente com uma sociedade como a portuguesa, cujo modelo de desenvolvimento permitiu que as elites sociais e políticas reservassem para si um papel comparativamente superior àquele que noutros casos nacionais as elites conseguiram preservar, percepcionando a generalidade dos processos de mudança social como produto do impulso das elites, ou de segmentos delas, e raramente como processos mais ou menos espontâneos originados no seio das massas populares e dos grupos sociais dominados. Em minha opinião, não somente as elites conservadoras que se sentiram ameaçadas pelo processo revolucionário de 1974-76 embarcaram neste tipo de explicações, como já em 1910 ou em 1820 haviam embarcado, se analisarmos a história das direitas contemporâneas portuguesas e a sua particular leitura da História; também no seio das elites autorrepresentadas como progressistas este mesmo comportamento pode ser detectado, ainda que, naturalmente, o sentido da sua leitura história seja o inverso. 
Em qualquer caso, viveu-se naqueles anos uma experiência absolutamente única de participação política, dificilmente comparável, pela intensidade e duração, a qualquer outra europeia desde o início da Guerra Fria. A rua tornara-se um espaço permanente de manifestação. A primeira convocatória de eleições com sufrágio universal, em Abril de 1975, mobiliza 91,2\% dos inscritos. Até 1983, a participação eleitoral nas legislativas mantém-se bastante acima dos 80\% $(83,3 \%$ em 1976, 87,5\% em 1979, 83,1\% em 1980), um nível significativamente mais elevado do que na Espanha dos mesmos anos, envolvida no processo da Transição, por exemplo, e, há que sublinhá-lo, do que em quaisquer eleições desde então. Nos organismos sociais verte-se o grosso dessa participação, desde as assembleias e os comités de empresa aos sindicatos, nas cooperativas de autogestão que resultam do abandono patronal de uma infinidade de empresas, nas comissões de moradores organizadas informalmente. Nestas muito variadas experiências, geraram-se em última análise os sistemas de gestão democrática dos organismos públicos e as entidades independentes de controlo dos serviços públicos que se consolidaram no período constitucional.

De tudo isto, resulta uma sociedade muito mais livre, substancialmente mais laica, com o passar do tempo mais urbana ou urbanizada, na qual a maioria da população se pode permitir valorizar mais o capital escolar, e que, por conseguinte, dispõe de mais oportunidades distribuídas de forma significativamente menos desigualitária, que consome muitos mais produtos culturais do que no passado, e, apesar de concluída a massificação social do consumo dos media, muito mais diversificados.

Especialmente significativa é a mudança no universo feminino. As mulheres portuguesas ocupam boa parte do espaço público do qual antes estavam ausentes, recuperando em pouco tempo muito do caminho entretanto percorrido pelas mulheres da Europa. Por alturas do final da década, as mulheres trabalham muito mais fora do reduto doméstico e familiar, ocupam a maior parte dos lugares discentes do ensino secundário (aqui também dos lugares docentes) e superior; dentro da família, consagra-se o direito ao divórcio para os matrimónios católicos (1975) e a reforma do Código Civil (1976), que instaura a igualdade total de direitos entre homens e mulheres e revoga legalmente princípios e conceitos do passado que se haviam tornado inaceitáveis para a maioria da sociedade, como a subordinação da mulher dentro do casal e da família, a ilegitimidade dos nascidos fora do matrimónio ou a perseguição legal dos homossexuais. ${ }^{18}$

O universo das relações laborais é aquele em que o fenómeno revolucionário terá operado transformações mais profundas. Um sem fim de reivindicações históricas do movimento dos trabalhadores encontra a sua consagração legal: o salário mínimo, o direito à contratação colectiva, a greve, a restrição do direito pa-

${ }^{18}$ Cf. Ana Nunes de AlmEIDA e Karin WALL, «Família e quotidiano: movimentos e sinais de mudança», in BRITO, 2001. 
tronal do despedimento, que passa a ser submetido a um critério de «justa causa», a universalização dos sistemas públicos de segurança social, o controle político dos preços dos «bens de primeira necessidade»... 1974 e, sobretudo, 1975 são anos de um aumento muito significativo do nível retributivo: os salários reais beneficiaram de um crescimento de 12\% em 1974 e de 9\% em 1975 (cf. LEÃO, 1992: 177).

A esquerda política e social fracassará, isso sim, na defesa do Estado de Bem Estar como legado inexpugnável daquilo a que se chamariam as conquistas da Revolução. Antes de qualquer outra consideração, porque se deu conta que não tivera tempo de lançar as bases da sua construção, e havia antecipado etapas na sua edificação. Procurava-se atribuir ao sistema escolar particulares capacidades de correcção da discriminação social, ampliando a escolaridade obrigatória (dos seis anos adoptados em 1964, sob a ditadura, para os nove que não se adoptariam antes de 1986), declarando todo o sistema gratuito quando obrigatório, e «tendencialmente gratuito» nos seus níveis subsequentes. Não obstante, os desequilíbrios sociais e regionais engoliam as transformações legais, sabotando-as com obstáculos como os níveis elevadíssimos de fracasso e abandono escolar, o elitismo das práticas curriculares e a óbvia incapacidade do sistema escolar de alterar profundamente a própria lógica da sociedade.

No campo da saúde, as resistências corporativas à construção de um Sistema Nacional de Saúde e a evidente falta de empenho dos Governos pósrevolucionários, contemporâneos já da vaga neoliberal que varria entretanto a Europa, em opor-se à hegemonia dos interesses privados, configurou um verdadeiro paradoxo histórico no caso português: quando, trinta anos depois do final da II Guerra Mundial, se reuniram as condições políticas para tentar universalizar em Portugal políticas sociais, o ambiente politicoideológico na Europa ocidental começava a mudar, ajudado pela conjuntura de recessão económica internacional, invertendo a grande aposta no Welfare State e gradualmente reduzindo o empenho governativo na sua prossecução.

BENEFICIÁRIOS E RECURSOS DAS POLÍTICAS SOCIAIS (cf. BARRETO, 1996: 99, 134-35, 417)

\begin{tabular}{|l|c|c|c|c|}
\hline & 1960 & 1970 & 1975 & 1980 \\
\hline Beneficiários Segurança Social $^{1}$ & $1.187,4$ & $2.386,7$ & $3.288,7$ & $3.733,1$ \\
\hline Gastos Segurança Social/P.I.B. & $1,7 \%$ & $3,8 \%$ & $9,1 \%$ & $8 \%$ \\
\hline Gastos públicos Educação/P.I.B. & - & $1,9 \% 2$ & $2,8 \%$ & $4,1 \%$ \\
\hline Gastos públicos Saúde/P.I.B. & $0,9 \%$ & $1,8 \%$ & $3,7 \%$ & $4,2 \%$ \\
\hline
\end{tabular}

1 Em milhares.

21972.

Estatisticamente, no entanto, não restam dúvidas de que o período pósrevolucionário, apesar de todas as suas contradições, lançou as bases de um empen- 
ho mais forte por parte do Estado português na sua função social, sobretudo com a universalização legal de cobertura da Segurança Social. Contudo, de modo muito mais telúrico, são as grandes mobilizações populares dos anos 1974 e 1975 que alteram o aspecto, pelo menos esse, do país.

Por todo o lado, se bem que muito mais no Sul do que no Norte, ocupam-se casas e constituem-se comissões de moradores que se autoatribuem funções de gestão local dos bairros, algumas conseguindo a colaboração de distintos activistas e/ou técnicos que desencadeiam procedimentos espontâneos de reestruturação urbana de áreas degradadas, escapando a um controle efectivo por parte dos poderes públicos institucionais. ${ }^{19}$ Os movimentos laborais reivindicativos, que evoluíam com demasiada rapidez em direcção ao mecanismo da greve, que, finalmente, deixara de ser (automaticamente) reprimida, expuseram ressentimentos, cumplicidades entre entidades patronais e Estado repressor, e uma infinidade de queixas e denúncias. Verificada pelo lado patronal a perda de controlo dos mecanismos de produção, os proprietários optaram pela fuga de capitais (cf. LEÃO, 1992: 179), seguida do abandono das suas empresas e até do País, constituindo, em Espanha, no Brasil ou na África do Sul, uma retaguarda de apoio aos ambientes conspiradores da ultradireita involucionista (cf. SÁNCHEZ, 1993).

De forma mais sequencial que contemporânea destes comportamentos, assembleias de trabalhadores decidem-se pela ocupação de empresas, que logo acabaram intervencionadas pelo Estado ou autogeridas pelas Comissões de Trabalhadores. Em alternativa, procede-se ao saneamento das hierarquias empresariais e de muito do pessoal técnico, tido como cúmplice dos antigos proprietários. As movimentações são, maioritariamente, dirigidas por activistas do PCP e da extrema esquerda, sobretudo a de matriz maoísta, que lhes disputa permamentemente a liderança e procura demonstrar o carácter burguês e revisionista dos anteriores; mais raramente, algum activista do PS apareceria envolvido nestes processos, mais habitualmente enquadrado em curiosas coligações com a extrema esquerda do que com comunistas.

Receoso dos efeitos desestabilizadores daquilo que poderia ser percebido como um excessivo impulso das reivindicações populares, O PCP actuou geralmente como elemento moderador nos primeiros meses posteriores ao 25 de Abril. O impulso da extrema esquerda e o desafio involucvionista terão conduzido, a partir de inícios de 1975, a uma transformação substancial do papel desempenhado pelos comunistas, que embarcam numa competição com os grupos à sua esquerda, contribuindo para radicalizar as lutas operárias.

Nesse ano, sobretudo a partir do fracasso do golpe spinolista de 11 de Março, o Estado, num processo que «resultou sobretudo de factos consumados impostos pelas forças político-sociais dominantes no momento, não tendo obedecido a

19 Cf., como estudo à escala local, Maria Rodrigues (1999), Pelo direito à cidade. O movimento de moradores no Porto (1974/76). Prefácio de Gaspar Martins Pereira. Porto: Campo das Letras. 
nenhum plano consciente e previamente elaborado", nacionaliza várias empresas, começando por todo o sector da banca e seguros, nas mãos de uns quantos grupos económicos - os chamados sete magníficos - que, até então, controlavam amplíssimos sectores da economia. Daqui resultou um «sector empresarial do Estado, que até então tinha tido uma dimensão e significado praticamente irrisórios, e que atingiu uma importância e uma proporção muito próximas das da generalidade dos países da Europa Ocidental» (LEÃO, 1992: 175).

Provavelmente, o mais simbólico dos movimentos sociais, entre todos os que poderiam escolher-se como representativos do período revolucionário, terá sido o das ocupações de terras, «fortíssimo indício da diversidade social, cultural e política da realidade nacional» (FERREIRA, 1993: 121), já que se concentrou quase exclusivamente na área da grande propriedade fundiária, ou seja, praticamente toda a metade meridional do país (Alentejo, boa parte do Ribatejo, franjas da Beira Baixa e do Algarve) - aquela que se chamará Zona de Intervenção da Reforma Agrária (Z.I.R.A.).

Distinguem-se três fases (cf. BARROS, 1981: 60-75) no processo, numa sequência de aceleração. Na primeira, entre o final de 1974 e Julho de 1975, a paralisia total dos investimentos e das contratações e o abandono patronal das propriedades empurra os trabalhadores, ainda pouco enquadrados pelos sindicatos agrícolas, para a realização das primeiras ocupações, que correspondem a cerca de um oitavo das terras que se ocuparão até ao final do período. A segunda decorre no chamado Verão Quente da Revolução portuguesa, Agosto-Setembro de 1975, e nela se procede, já sob a acção dirigente dos sindicatos agrícolas hegemonizados pelo PCP, a um conjunto de ocupações que correspondem a um pouco mais de um quarto das terras ocupadas, conseguindo-se politicamente a legalização do movimento através da expropriação e da nacionalização das grandes propriedades envolvidas. A terceira, por fim, cobre o último trimestre de 1975 e Janeiro de 1976, período dividido em duas metades pelo golpe militar moderado de 25 de Novembro de 1975 que encerra a breve hegemonia política da esquerda militar, mas que, contudo, não evita, por algum tempo, a onda de ocupações, que nesta última fase compreendem cerca de $60 \%$ da terra socializada (CF. todos os cálculos proporcionais em BARRETO, 1989: 459). Em circunstâncias políticas crescentemente hostis, os ocupantes da terra procuravam nessa fase consolidar 0 processo, ampliando-o, e arrancar do Estado um compromisso de crédito de emergência.

De todo o processo resulta a socialização de $35 \%$ do território da Z.I.R.A.; esta, por sua vez, representava $41 \%$ da superfície do território peninsular português e $46 \%$ da sua superfície agrícola cultivada. Neste terço da metade Sul de Portugal, "sem que houvesse um projecto claro de qual o tipo de unidade de produção que deveria suceder ao sistema capitalista fundiário» (BARROS, 1981: 107), constituem-se, durante aqueles anos, meio milhar de Unidades Colectivas de Produção (U.C.P.'s) sobre uma propriedade do solo legalmente transferida para as mãos do 
Estado, que, no seu conjunto, empregam 60 mil trabalhadores..$^{20}$ Por seu turno, passa a operar um muito débil sector cooperativo, sintomaticamente associado àqueles que politicamente confluíram no Partido Socialista (PS).

A estratégia de legalizar a Revolução conduziu à inclusão no texto constitucional de um conjunto de preceitos que procurava assegurar a irreversibilidade legal da apropriação colectiva da grande propriedade fundiária, e desse modo resguardar, com a lei na mão, a Reforma Agrária das transformações políticas que se aproximavam. Não obstante a boa implantação eleitoral do PCP em todo o território da Z.I.R.A. (33,4\% e $37,6 \%$ dos votos nas duas eleições parlamentares de 1975 e 1976), que lhe permitiu controlar um segmento muito consistente do respectivo poder local (com $41,8 \%$ dos votos) nas primeiras eleições municipais de 1976 (cf. As Eleições..., 1980), os comunistas, a extrema esquerda e alguns elementos da ala esquerda socialista (que se reviam sobretudo no seu dirigente Lopes Cardoso) foram incapazes de impedir o início da reversão legal definitiva do movimento de ocupações uma vez aprovada, pelo primeiro Governo socialista de Mário Soares com a ajuda da direita parlamentar, a Lei Barreto (Lei n. ${ }^{\circ} 7 / 77,29$ de Setembro). O fenómeno ficava politicamente liquidado com a primeira revisão da Constituição, em 1982, culminando um processo de esvaziamento da Reforma Agrária seguida pelos Governos socialistas, conservadores e mistos.

\subsection{Descolonização e fim da identidade imperial/lusotropicalista}

Massificação social, democracia política e descolonização ficaram como os legados fundamentais do período revolucionário que ocupa a franja central dos anos '70 em Portugal. Um tríptico que, no seu conjunto, nada tinha a ver com o projecto marcelista de reformismo controlado, concebido mais para o Portugal do imediato pós-II Guerra Mundial que para aquele que passava por um transe (a expressão importo-a de Medeiros Ferreira) tão extraordinário como aquele que procurei aqui descrever para essa última quinzena de anos de vida da ditadura.

O movimento explicitamente descolonizador vertido na lei n. ${ }^{\circ} 7 / 74$, de 27 de Julho, ao assumir que «o princípio de que a solução das guerras do Ultramar é política e não militar (...), implica, de acordo com a Carta das Nações Unidas, o reconhecimento do direito dos povos à autodeterminação", e de que este, "com todas as suas consequências, inclui a aceitação da independência dos territórios ultramarinos» (arts. $1 .^{\circ}$ e $2 .^{\circ}$ ), abriria caminho, eliminado Spínola como seu obstáculo institucional, ao reconhecimento da independência da Guiné-Bissau (29 de Agosto de 1974), unilateralmente proclamada em Setembro de 1973, e da sobe-

20 Sobre todo o processo, cf. também Lino de CARVALHO (2004), Reforma Agrária. Da utopia à realidade. Porto: Campo das Letras; António Murteira (dir.) (2004), Uma revolução na revolução. Reforma Agrária no Sul de Portugal. Porto: Câmara Municipal de Montemor-o-Novo/Campo das Letras; e Fernando Oliveira BAPTISTA, «O 25 de Abril, a sociedade rural e a questão da terra», in BRITO, 2001. 
rania que a Índia exercia desde 1961 sobre Goa, Damão e Diu (31 de Dezembro de 1974); à proclamação das independências de Cabo Verde (5 de Julho de 1975), São Tomé e Príncipe (12 de Julho), Moçambique (25 de Setembro) e Angola (11 de Novembro); e à definição constitucional de Macau como «território sob administração portuguesa" sem fazer parte do território nacional (Constituição de 1976), abrindo, por sua vez, o caminho à negociação da sua tranferência em direcção à soberania chinesa que se concluiu em Dezembro de 1999. Apenas a invasão de Timor Leste por parte de tropas indonésias (7 de Dezembro de 1975), quatro meses depois de o Estado português ter reiterado o reconhecimento do direito do povo timorense à autodeterminação, interromperia um processo já iniciado, que se retomaria com o referendo de 1999 a que o regime indonésio se viu obrigado depois de 24 anos de resistência.

Encerrou-se, assim, e definitivamente, o ciclo colonial da História portuguesa, que tão larga influência e pesado lastro impôs aos portugueses contemporâneos, operando decisivamente na crise da Monarquia Constitucional e do Estado Novo e contribuindo indirectamente (impulsionando o Governo português para a intervenção na guerra mundial) para a crise da Primeira República. Deste processo histórico resultou uma redefinição radical da identidade histórica e política de Portugal, que muitos, entre os quais me encontro, interpretaram na sua essência como fenómeno de libertação do povo português e de todos os que the haviam estado submetidos no seu domínio colonial. Nas pouco recordadas palavras de Costa Gomes diante da Assembleia Geral das Nações Unidas, na primeira comparência de um Presidente português nesse fórum, em Outubro de 1974, nós, os portugueses, «não mais admitiremos trocar a liberdade de consciência colectiva por sonhos grandiosos de imperialismo estéril».

Não nos surpreenderá, contudo, que num país com as dimensões de Portugal, numa sociedade que teve de amadurecer e realizar mudanças tão radicais num tão curto período da sua História recente, este (o colonialismo, a Guerra CoIonial, a descolonização) continue a ser um problema de identidade, de memória e de falta de capacidade de perceber e assumir todos os danos infligidos a outros, àqueles que foram submetidos à soberania colonial portuguesa e que, por isso mesmo, se viram envolvidos violentamente em processos de transformação interna da sociedade portuguesa cujas consequências não se ficaram pelo interior das suas fronteiras estritas. Sem querer, na conclusão deste ensaio, iniciar uma discussão que supera as suas intenções, reconheçamos que, enquanto comunidade nacional, estamos longe de reflectir com frontalidade e honestidade intelectual nas muito sérias repercussões que este processo histórico teve em nós próprios e nos povos afroasiáticos que nos estiveram submetidos. Esta é, pelo menos, a sensação que se desenha diante de nós quando tomamos pulso aos matizes da opinião publicada, a autobiografia, a ficção literária, cinematográfica ou televisiva, e a publicística escassamente produzidas sobre o tema nos trinta anos que decorreram já desde a Revolução dos Cravos, que nos tem permitido continuar a descrevermo-nos, histórica e eticamente, mais como vítimas do que 
responsáveis (da dominação colonial, da guerra, da descolonização) — numa autorrepresentação curiosamente próxima daquela que, durante longos anos, alemães e austríacos, por exemplo, fizeram de si próprios relativamente à experiência nazi e às suas consequências...

\section{REFERÊNCIAS BIBLIOGRÁFICAS}

Maria loannis BAGANHA (1999), «Emigração», in BARRETO, António; MÓNICA, Maria Filomena (coords.), Dicionário de História de Portugal, vol. VII/Suplemento A/E. Porto: Figueirinhas, pp. 615-18.

António BARRETO (1989), «Reforma Agrária e Revolução em Portugal (1974-1976)», in Mário Baptista COELHO (coord.), Portugal. O sistema político e constitucional, 1974-1987. Lisboa: Instituto de Ciências Sociais da Universidade de Lisboa, pp. 453-468.

António BARRETO (1996) (org.), A situação social em Portugal, 1960-1995. Lisboa: Instituto de Ciências Sociais.

Afonso de BARROS (1981), A reforma agrária em Portugal - Das ocupações à formação das novas unidades de produção, 2. ${ }^{\text {a }}$ ed.. Oeiras: Instituto Gulbenkian de Ciência.

Gerald J. BENDER (1980), Angola sob o domínio português. Mito e realidade, trad. port. [ed. ori. norteamericana: 1976]. Lisboa: Livraria Sá da Costa.

J.M. Brandão de BRITO (coord.) (2001), O país em revolução. Revolução e democracia. Lisboa: Editorial Notícias.

Conceição CERDEIRA, Edite PADILHA (1990), A sindicalização e alguns comportamentos sindicais. Lisboa: Ministério do Emprego e Segurança Social/Direcção-Geral do Trabalho.

(1990), CGTP-IN - 20 anos com os trabalhadores (Breve memória), 2 cadernos. S.I.: CGTP-IN.

Custódio CÓNIM [1992], «As incidências demográficas das alterações político-económicas», in REIS, António (dir.), Portugal Contemporâneo, vol. VI [1974- ]. Lisboa: Publicações Alfa, pp. 225-44.

Pedro Pezarat CORREIA (1999), «Descolonização», in J. M. Brandão de BRITO (coord.), Do Marcelismo ao fim do Império. Lisboa: Editorial Notícias, pp. 101-224.

Manuel Braga da CRUZ [1980], As origens da democracia cristã e o salazarismo. Lisboa: Editorial Presença/Gabinete de Investigações Sociais.

Eduardo DÂMASO (1999), A invasão spinolista, 2. ${ }^{a}$ ed. [1. a.: Círculo de Leitores]. Lisboa: Fenda.

(1980), Eleições no Portugal de Abril, As. Lisboa: Editorial Avante

João de Menezes FERREIRA (1994), «Os sindicatos. As associações patronais», in António REIS (coord.), Portugal. 20 anos de democracia. S.I.: Círculo de Leitores, pp. 160-69.

José Medeiros FERREIRA [1993], Portugal em transe (1974-1985), vol. VIII de José MATTOSO (dir.), História de Portugal. S.I.: Círculo de Leitores.

Emanuel Reis LEÃO [1992], «Das transformações revolucionárias à dinâmica europeia», in REIS, António (dir.), Portugal Contemporâneo, vol. VI [1974- ]. Lisboa: Publicações Alfa, pp. 173-224.

Susana MARTINS (2001), Socialistas na oposição ao Estado Novo. Um estudo sobre o movimento socialista português (1926-1974). Cruz Quebrada: Casa das Letras/Editorial Notícias.

Dawn Linda RABY [1990], A resistência antifascista em Portugal. Comunistas, democratas e militares em oposição a Salazar, 1941-1974, trad. port. [Ed. ori: (1988). Fascism and resistance in Portugal. Communists, liberals and military dissidents in the opposition to Salazar, 19411974. Manchester: Manchester University Press]. Lisboa: Edições Salamandra

Fernando ROSAS (2004), Pensamento e acção política. Portugal século xx (1890-1976). Lisboa: Editorial Notícias.

Fernando ROSAS [2004a], «Prefácio. Marcelismo: ser ou não ser», in Fernando ROSAS; Pedro Aires OLIVEIRA (coords.), A transição falhada. O Marcelismo e o fim do Estado Novo (1968-1974). S.I.: Círculo de Leitores.

Josep SÁNCHEZ CERVELLÓ (1993), A Revolução portuguesa e a sua influência na transição espanhola (1961-1976). Lisboa: Assírio \& Alvim.

Josep SÁNCHEZ CERVELLÓ (1996), «Las Fuerzas Armadas durante la revolución portuguesa: autonomía y reorganización (1974-1976)", in Hipólito de la TORRE GÓMEZ (ed.), Fuerzas Armadas y poder político en el siglo xx de Portugal y España (VI Jornadas de Estudios Luso-Españoles). Mérida: U.N.E.D./Centro Regional de Extremadura, pp. 243-73.

Américo Ramos dos SANTOS (1989), «Abertura e bloqueamento da economia portuguesa», in REIS, António (dir.), Portugal Contemporâneo, vol. V [1958-1974]. Lisboa: Publicações Alfa, pp. 109-50. 
Joel da SILVEIRA (1989), "As guerras coloniais e a queda do Império», in REIS, António (dir.), Portugal Contemporâneo, vol. V [1958-1974]. Lisboa: Publicações Alfa, pp. 71-106.

Mário SOARES, «Socialismo», (1996), in Fernando ROSAS; J.M. Brandão de BRITO (dir.) Dicionário de História do Estado Novo, vol. 2. S.I.: Círculo de Leitores, pp. 935-39.

José Carlos VALENTE (1996), "Sindicatos Nacionais», in Fernando ROSAS; J. M. Brandão de BRITO (dir.), Dicionário de História do Estado Novo, vol. 2. S.I.: Círculo de Leitores, pp. 916-23. 